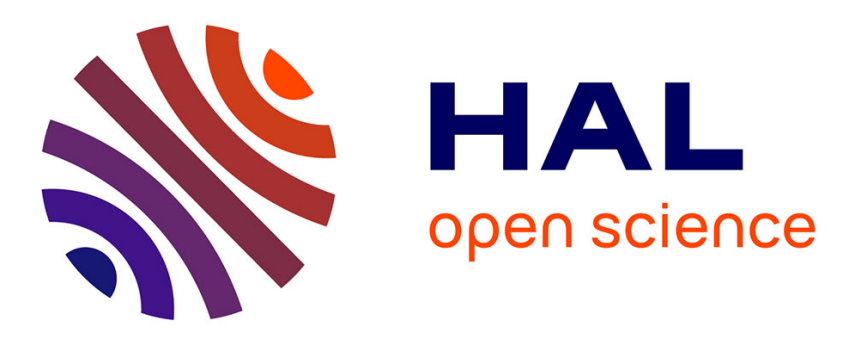

\title{
Inferences on Sicilian Mesolithic subsistence patterns from cross-sectional geometry and entheseal changes
}

V. Sparacello, M. Samsel, S. Villotte, Alessandra Varalli, V Schimmenti, L. Sineo

\section{- To cite this version:}

V. Sparacello, M. Samsel, S. Villotte, Alessandra Varalli, V Schimmenti, et al.. Inferences on Sicilian Mesolithic subsistence patterns from cross-sectional geometry and entheseal changes. Archaeological and Anthropological Sciences, 2020, 12 (5), 10.1007/s12520-020-01044-y • hal-02733204

\section{HAL Id: hal-02733204 \\ https://hal.science/hal-02733204}

Submitted on 16 Nov 2020

HAL is a multi-disciplinary open access archive for the deposit and dissemination of scientific research documents, whether they are published or not. The documents may come from teaching and research institutions in France or abroad, or from public or private research centers.
L'archive ouverte pluridisciplinaire HAL, est destinée au dépôt et à la diffusion de documents scientifiques de niveau recherche, publiés ou non, émanant des établissements d'enseignement et de recherche français ou étrangers, des laboratoires publics ou privés. 
Title: Inferences on Sicilian Mesolithic subsistence patterns from cross-sectional geometry and entheseal changes.

Authors: Sparacello VS (1*), Samsel M (1), Villotte S (1), Varalli A (2), Schimmenti V (3), Sineo L (4).

1 - Univ. Bordeaux, CNRS, MC, PACEA, UMR 5199, 33615 Pessac, France

2 - Department of Archaeology, Durham University, UK

3 - Museo Archeologico Regionale “Antonino Salinas”, Palermo, Italy

4 - Dipartimento di Biologia Ambientale e Biodiversità, Università degli Studi di Palermo, Palermo, Italy

Corresponding Author: Vitale Stefano Sparacello; PACEA - UMR 5199 Université de Bordeaux Bâtiment B8 Allée Geoffroy Saint Hilaire CS 5002333615 PESSAC CEDEX: vitale.sparacello@u-bordeaux.fr; vitosparacello@gmail.com

Keywords: Sicilian Mesolithic, cross-sectional geometry, functional adaptations, entheseal changes, subsistence patterns, mobility.

\begin{abstract}
Using cross-sectional geometry (CSG), entheseal changes (ECs), and presence of external auditory meatus exostosis (EAE), this study tests hypothesis - bases on isotopic and zooarchaeological evidence - that in the Sicilian Mesolithic terrestrial rather than marine resources were predominantly exploited, in substantial continuity with previous Epigravettian hunters. Results show similarities in the general frequency of ECs - a rough proxy for overall activity - with Late Pleistocene hunters, in contrast with Mesolithic coastal foragers or Neolithic herders/farmers. Yet, CSG suggests that this possible continuity in the type of resources exploited was accompanied by a behavioral change, and in particular the abandonment of the throwing technology, possibly in favor of new tools such as traps and the bow and arrow. In fact, the dramatic decrease in humeral bilateral asymmetry documented at a European level with the Pleistocene-Holocene transition can be found also in the Sicilian Mesolithic. Results for the lower limb appear compatible with a certain degree of terrestrial mobility in a rugged environment. The frequency of EAE suggests that activities related to water were present but not common; however, their prominence is difficult to determine
\end{abstract}


given the small sample size. The pattern of information provided by the proxies for activity used here is complex and partially contrasting, but has the potential to integrate and enrich archaeological methods and biochemical approaches. This study corroborates a varied scenario of continuity and discontinuity in subsistence at the Pleistocene-Holocene transition, and highlights the importance of a regional bioarchaeological approach of human biological and behavioral adaptations.

\section{Introduction}

Human adaptive strategies appear to have been strongly impacted by the major climatic oscillations that happened with the Last Glacial Maximum (LGM; c. 20,000 years BP; Clark et al. 2009) and the following de-glaciation, which marks the end of the Pleistocene. The Pleistocene-Holocene boundary is conventionally placed at 10,000 BP [e.g., Mangerud et al., 1974; or c. 11,700 yr b2k (before AD2000; Walker et al., 2009) using polar ice cores; see also Lowe and Walker, 2000]. The various techno-cultural complexes comprised between the last Upper Paleolithic cultures and the diffusion of the Neolithic agricultural "package" between 8-5,000 BP (Bogucki, 2001; Zvelebil, 2001) are generally called “Mesolithic”.

Parallel to the major environmental changes that occurred all over Europe during glaciation and deglaciation, shifts in subsistence practices took place alongside cultural diversification and fragmentation. The pre-LGM inhabitants of Europe appear to have focused on hunting mid- to large-size ungulates, which consisted mainly of red deer and ibex in peninsular Italy (Mussi et al., 2000; Mussi 2001; Bocherens et al. 2015; Wojtal and Wilczyński 2015a,b; Drucker et al. 2017). Indeed, most of the isotopic investigations conducted on the Early Upper Paleolithic humans suggest important consumption of animal protein, namely terrestrial herbivores (Richards 2009). Climatic cooling forced human groups into southern refugia, where they had to intensify exploitation of existing resources and increasingly acquire high-cost/low-yield resources, such as marine and freshwater fish, shellfish, and hunting small game such as birds (Straus et al. 1981; Clark and Straus 1986; Stiner et al. 1999; Mussi 2001; Richards et al. 2001). After the LGM, the arid glacial steppe gradually gave way to a more varied environment, with an increase in the presence of trees culminating into the mesophyll Holocenic forest (Gamble 1986; Ravazzi et al., 2007; Magri, 2008). While coastal plains shrank and disappeared, high mountain ranges became accessible, and entire portions of the continent could be recolonized. Within this framework, the Italian peninsula, 
due to its complex geomorphology, presented a variety of niches for human adaptation, from coastal lagoons and marshes to hillsides and mountains (Mussi 2001).

Subsistence practices of Late Upper Paleolithic human groups reflect this increased ecological diversity. Hunting of large mammals endured in those areas where they survived (Richards et al., 2000; Germonpré et al., 2008; Jacobi and Higham 2009; Garcia- Guixe et al., 2009), but also the exploitation of both freshwater or marine and terrestrial resources continued (Richards et al. 2001, 2005; Stiner and Munro 2011; Gazzoni et al. 2013; Mannino et al. 2011a,b). Depending on the local ecologies, in some areas the terrestrial (Cassoli and Tagliacozzo 1994; Richards et al. 2000; Craig et al. 2010; Stevens et al. 2010; Mannino et al. 2011a,b) or the marine/freshwater component (Richards at al. 2005, 2015) became predominant. This anticipated what happened in the Mesolithic, when at coastal and estuarine sites in the Baltic, UK, Croatia, Portugal, Spain and France, up to 100\% protein in the diet is supposed to have derived from the sea (Richards and Mellars 1998; Mannino and Thomas 2001; Schulting and Richards 2002; Richards et al. 2005; Cristiani et al. 2018; Salazar-García et al. 2014; 2018). The explanation provided for this shift is that expanding groups of hunters turned to the exploitation of marine and freshwater resources in those areas, such as the Baltic, where river estuaries, vast intertidal areas, and high sea productivity make it advantageous (Zvelebil 2008). Archaeological evidence suggests that, in the Mediterranean, Mesolithic groups continued to base their subsistence on the exploitation of terrestrial animals, including high-altitude hunting in the Alpine and Apennine areas (Fontana et al. 2009; Moore 2014; Fontana and Visentin, 2016), with no or little contribution of marine and freshwater resources (Stiner and Munro 2011; Mannino et al. 2011a, 2012). This may be due to a lower productivity of the Mediterranean Sea (Fa, 2008; Diniz, 2016) or to the possibility that sites bearing abundant evidence of marine food exploitation were submerged by rising sea levels (Bailey and Flemming, 2008). Nevertheless, direct biochemical evidence from human remains via isotopic analysis supports the scenario of a diet mainly based on terrestrial resources (Garcia-Guixe et al., 2006; Paine et al., 2009; Lightfoot et al., 2011; Mannino et al, 2011a,b; Mannino et al., 2012; Goude et al. 2017).

Biomechanical properties and patterns of enthesopathies can provide data on subsistencerelated functional adaptations and alterations (Pearson and Lieberman, 2004; Ruff et al., 2006b; Villotte 2009). When pooling skeletal remains from Europe, Upper Paleolithic people show lower limb adaptations/alterations related to high mobility levels, while according to the same traits, Mesolithic groups appear to have been more sedentary (Holt 1999, 2003; Holt 
et al. 2000; Holt and Formicola 2008; Villotte et al, 2010; Shaw and Stock 2013; Sparacello et al., 2018). In addition, Mesolithic skeletal assemblages do not show the high levels of humeral bilateral asymmetry in mechanical rigidity that were one of the hallmarks of Late Pleistocene hunters (Sládek et al., 2016; Sparacello et al., 2017; Villotte et al., 2017). These results are in agreement with a shift from a highly-mobile subsistence based on hunting, especially using throwing technology, to a more sedentary exploitation of coastal and estuarine resources (e.g. Marchand et al., 2016).

However, the variability in Mesolithic subsistence regimes evidenced by the archaeological and isotopic analyses outlined above requires a more regional approach in order to explore subsistence-related habitual behaviors via skeletal functional adaptations. This study focuses on Mesolithic human remains from three nearby sites on the coast of western Sicily: Grotta d'Oriente in the Favignana Island (which was probably attached to the Sicilian mainland in the Mesolithic; Mannino et al., 2012), Grotta della Molara near Palermo, and Grotta dell’Uzzo near San Vito lo Capo (Figure 1). Archeozoological and isotopic studies suggest that the Pleistocene-Holocene transition in western Sicilian sites did not result in a major shift in subsistence regimes. In fact, Mesolithic foragers appear to have not developed strongly marine-oriented adaptations, but continued a subsistence mainly based on hunting terrestrial mammals (Tagliacozzo, 1993; Mannino and Thomas, 2009; Mannino et al., 2012). This should result in a substantial continuity in skeletal functional adaptations between Pleistocene and Sicilian Mesolithic foragers. We will test this hypothesis through the cross-sectional geometry method (CSG), and the study of entheseal changes (EC). Furthermore, we will assess the prevalence of external auditory canal exostosis (EAE), which has been associated with frequent contact with cold water (see Villotte and Knüsel 2016 for a review). Although the resulting sample size is small (13 individuals, which are detailed below), we surveyed for this study totality of the Mesolithic individuals in this area, in order to attempt to capture as much as possible the Sicilian Mesolithic variability of human bone functional adaptations and alterations.

Figure 1 about here

\section{Materials and methods}

Data were collected from 13 Sicilian Mesolithic adult individuals (Table 1): one from the site of Grotta d’Oriente (8730-8570 cal BC; Di Salvo et al., 2012a; Mannino et al., 2012), two from Grotta della Molara (c. 7960-7470 cal BC; Borgognini Tarli 1976; Canci et al., 1995; 
Gowlett et al., 1987), and ten from Grotta dell’Uzzo (AMS on Uzzo IV: 8750-8300 cal BC; AMS on shell with Uzzo XI: 7850-7510; Di Salvo et al., 2012; Borgognini Tarli, 1980; Borgognini Tarli and Repetto, 1986; Borgognini Tarli et al., 1993; Mannino et al., 2015). Albeit fragile, bones are generally in a good state of conservation, with a level of completion and surface preservation sufficient for both CSG reconstruction and evaluation of ECs.

Sex was re-assessed by MS (Samsel, 2018) based on pelvic morphology and morphometry (Bruzek 2002; Murail et al. 2005; Bruzek et al., 2017) and using the secondary sex diagnosis (see Murail et al. 1999), and is sometimes in disagreement with previous studies, mostly in the direction of considering previous determination as “undetermined” (cf. Borgognini Tarli 1980, 1993; Alciati et al., 2005; Samsel, 2018; Table 1). Detailed tables for sex estimations, including the results for each methodology used, are available in Samsel (2018). Age at death estimation was based on the state of fusion of later-fusing secondary centers of ossification, following Owings Webb and Suchey (1985) and Albert and Maples (1995), on the surface characteristics of the pubic symphyseal face, and on the form of the sacroiliac surface of the os coxae, following Schmitt's methods (Schmitt, 2005; Schmitt and Georges, 2008). Given the well-known limitations in the precision of age at death estimation, most individuals fall under the "adult” category (or 20-39 and > 30 years old), one can be considered “old” (Grotta d'Oriente B, probably > 50 years old), and three appear to be young adults (20-29 years old, Table 1).

\section{[Table 1 about here]}

The biomechanical analysis of postcranial functional adaptations employs the cross-sectional geometry method (CSG), which is based on the widely accepted notion that bone tissue optimizes to its mechanical environment so as to maintain physiological strains within the normal limits (“Wolff's Law”, better referred to as "bone functional adaptation”; Pearson and Lieberman, 2004; Ruff et al., 2006b). Bone tissue is deposited in the shaft's cross-section where mechanical loads require it to prevent strains in excess of the elastic limit, whereas below a certain strain threshold, the bone tissue is reabsorbed. By analyzing the crosssections of the diaphysis at specified percentages of bone length, it is therefore possible to obtain variables that correlate with the bending moments (second moments of area: Ii) and overall torsional rigidity (polar moment of area: $\mathrm{J}$ ) of the diaphysis (all moments of area are expressed in $\mathrm{mm}^{4}$ ). Although the complexity of the factors influencing bone robusticity should always be taken into account when interpreting CSG results (Pearson and Lieberman, 
2004), it is generally presumed that variation in CSG properties correlate with activity levels and types once the effect of body size is factored out (Ruff et al., 2006b). Following this rationale, the integration of quantitative data derived from CSG with ethnographic and archaeological information has been widely used in reconstructing the mechanical environment of past and recent populations and to make inferences about their subsistence strategies, mobility levels, and other habitual activities (reviews in Carlson and Marchi, 2014).

In this study, we reconstructed the cross sections (35\% and 50\% from the distal end for the humeri, and 50\% for the femur and tibia) from the surface 3D scans of the Sicilian Mesolithic individuals (collected using the DAVID SLS-2 structured light scanner), which were virtually positioned according to the reference planes following Ruff (2002). The cross sections were obtained using the function "slice” in Netfabb Standard 2018 for PC (copyright by Autodesk 2017), and CSG properties calculated using a version of the program SLICE (Nagurka and Hayes, 1980) adapted as a macro routine inserted in Scion Image release Beta 4.03. The "Solid CSG” method was employed to estimate actual CSG properties from the periosteal contour via regression equations (provided in Sparacello and Pearson, 2010; Marchi et al. 2011), as justified in previous research (Stock and Shaw, 2007; Sparacello and Pearson, 2010; Macintosh et al., 2013).

The variable expressing overall diaphyseal rigidity discussed in this study is calculated from the polar second moment of area ( $\mathrm{J}$ ) - corresponding to the torsional and (twice) average bending rigidity of the beam - raised to the power of 0.73 (Ruff, 1995, 2000). The value of $\mathrm{J}^{0.73}$ is proportional to the section modulus (Zp), which can be more precisely calculated dividing $\mathrm{J}$ by the average radius of the section. Although $\mathrm{J}^{0.73}$ is proportional to rather than strictly equivalent to Zp, we will refer to it as Zp, as done in previous research (e.g., Sparacello et al., 2011).

The mechanical loading on long bones is a function of physical activity, bone length, and body mass (Ruff, 2000). To isolate the effects of activity, the estimate of overall bone strength Zp was scaled for size dividing by bone mechanical length (as defined in Ruff, 2002) and body mass (Ruff, 2000). Body mass was estimated from the superoinferior diameter of the femoral head following the guidelines in Trinkaus and Ruff (2012).

In order to characterize the prevalent use of one arm in stressful activities, the degree of humeral bilateral asymmetry in J was calculated using the formula [(Jmax - Jmin)/Jmin]×100 
and expressed as a percentage, following previous studies (Trinkaus et al.,1994; Rhodes and Knüsel, 2005; Sparacello and Marchi, 2008; Sparacello et al., 2011). The resulting value represents an absolute (non-directional) asymmetry. Asymmetry was calculated from absolute values of $\mathrm{J}$ (i.e. not standardized by body size), because any prior size standardization would be elided.

Given their correspondence with mobility levels (Holt, 2003; Shaw and Stock, 2009a; Carlson and Marchi, 2014; Macintosh and Stock, 2018), lower limb CSG shape indices were also analyzed. For the femur, we consider the ratio between Ix (second moment of area in the anteroposterior plane) and Iy (second moment of area in the mediolateral plane). For the tibia, we used the ratio of Imax (maximum second moment of area) to Imin, (minimum second moment of area).

Lesions at tendon attachment sites (entheses) are called enthesopathies in the medical literature, whereas alterations visible on the skeleton are now called entheseal changes (ECs) in the anthropological literature (see Villotte and Knüsel 2013; Villotte et al. 2016). ECs have been associated with activity patterns in bioarcheological studies but, their reliability as indicator of past behaviors is still highly debated. It has been shown that a significant part of this issue is related to the methods used and the nature of entheses under study (Villotte 2006; 2009; Villotte et al. 2010; Villotte and Knüsel 2013). Many factors have been mentioned by biological anthropologists to explain the apparition of ECs, but from the medical literature three mains causes can be identified (see Villotte and Knüsel 2013 for a discussion): age (lesions at fibrocartilaginous entheses are more frequent in older individuals, especially after 50 years old), micro and macrotraumas, and systemic diseases (mainly DISH and spondyloarthropathies).

ECs were originally recorded using four generic scoring systems (Villotte 2006), allowing the comparison with other samples of Upper Paleolithic, Mesolithic and Neolithic individuals studied with the same method. It has been shown that biomechanical factors seem to play a significant role in the apparition of the ECs scored with the system 1 (Villotte 2009; Villotte et al. 2010) and the results provided here are only about this system. The system was originally created to score ECs at 5 upper limb entheses and 4 at the lower limb. However, it has been suggested that one them (the insertion of the $\mathrm{m}$. biceps brachii on the radius) may not be relevant for reconstruction of past behaviors (Villotte 2009; Villotte and Knüsel 2013a,b). ECs at 8 attachment sites are thus considered in the present paper, 4 on the humerus 
(m. subscapularis, mm. infra and supraspinatus, common flexors, common extensors), 1 one the coxal bone (mm. semimembranosus and biceps femoris) and 3 on the femur (m. gluteus minimus, m. gluteus medius, and m. iliopsoas).

Considering the low number of individuals, results are mostly presented in a descriptive way. Overall frequency of ECs (number of ECs/number of entheses scored) are computed. When controlled for age, this can be considered as an indicator of overall biomechanical stresses during life. Laterality was considered (the side of the upper limb with most ECs) as well as asymmetry (a difference of score between left and right site for a given upper limb enthesis).

External auditory exostoses (EAEs) are osseous exostoses that form in the external auditory canal resulting from an irritation of the periosteum. Many conditions can be responsible for this trait, but contact with cold water appears to be the main cause (for review of the medical and anthropological literature, see Kennedy 1986, Villotte and Knüsel 2016). EAE can be considered as one of the most informative of activity-related skeletal morphologies: it has a very well-known etiology, the amount of available clinical data is substantial, and it is possible to make comparisons of frequencies between current and past populations, with only minor methodological problems (Villotte and Knüsel 2016). One main issue should be emphasized though: the absence or low frequency of EAE in a small sample does not mean that contact with cold water was absent. Indeed, many individuals regularly in contact with cold water do not develop this exostosis. EAEs were recorded using a scoring system of the extent of occlusion previously applied by biological anthropologists (e.g. Crowe et al. 2010, Standen et al. 1997, Velasco-Vazquez et al. 2000, Villotte et al. 2014), and by clinicians (e.g. Cooper et al. 2010, Hurst et al. 2004).

The comparative samples for CSG properties and ECs consist of European Middle Paleolithic, Late Upper Paleolithic, and Mesolithic individuals, as well as an Italian Neolithic sample (Square Mouthed Pottery from Liguria; Varalli et al., In Press). Data were collected by the authors and from the literature (Tables 2 and 3). For EAEs, these samples are detailed in Villotte et al. 2014. For ECs, individuals displaying any changes indicating a possible systemic disease were discarded following the criteria presented in Villotte et al. (2010), and skeletal elements presenting signs of in vivo fractures were not scored.

The CSG parameters were variously obtained from CT scans, subperiosteal molds plus biplanar radiography for cortical thicknesses (LCM method; O’Neill and Ruff, 2004), ellipse formulae employing external diameters and cortical thicknesses (Holt, 1999), the "Solid 
CSG” method (Sparacello and Pearson, 2010), and scaled photographs of fossilization breaks. In addition, in some cases CSG properties were estimated from maximum and minimum subperiosteal diameters using the relevant least squares multiple regressions provided in Pearson and Sparacello (2017) and Sparacello et al (2017). The different techniques for obtaining cross-sectional parameters provide consistent results that are within the variation produced by the variable preservation of the fossil remains, and therefore can be pooled (cf. Macintosh et al., 2013; O’Neill and Ruff, 2004; Sparacello and Pearson, 2010; Stock, 2002).

Statistical analysis of CSG parameters involved ANOVA (main effect period) by sex for the variable normally distributed (Zp of all limbs), with post-hoc multiple comparisons (Bonferroni correction). For variables not normally distributed (shape indices and humeral asymmetry), a Kruskal-Wallis ANOVA with post-hoc multiple comparisons of mean ranks was performed. Boxplots and confidence intervals are provided in figures to best interpret possible differences among groups beyond the p-value results (Smith, 2017).

[Tables 2 and 3 about here]

\section{Results}

Table 4 contains the raw data used for the CSG analysis. Figure 2 shows the diachronic trend in humeral robusticity from the Middle Upper Paleolithic to the Neolithic (Ligurian skeletal series). Although the samples size is small, Sicilian Mesolithic individuals appear to consistently show the most robust humeri, especially in the left side, and particularly when compared to earlier Upper Paleolithic individuals (Table 5). Humeral bilateral asymmetry is significantly lower in the Sicilian Mesolithic sample than in earlier Paleolithic samples (Figure 3, and Table 5). Contrary to both Paleolithic and Neolithic samples, sexual dimorphism for upper limb robusticity and asymmetry is not significant in the Sicilian Mesolithic sample.

[Figures 2, 3 and Table 5 about here]

Figure 4 shows the diachronic trend in femoral and tibial robusticity and shape indices. Similarly to the humerus, both the femur and tibia of the Sicilian Mesolithic sample show higher robusticity than the comparative Upper Paleolithic, European Mesolithic, and Neolithic samples, especially in males (Table 6). The Sicilian Mesolithic males are also different than their European counterparts in not having a significantly lower femoral shape 
index when compared to the Paleolithic groups (Figure 4). In contrast, the tibial shape index Imax/Imin of Sicilian Mesolithic males is significantly lower when compared with the same groups (Figure 4; Table 6). Sexual dimorphism is not significant for all lower limb variables only in the European Mesolithic sample, while the Sicilian males have significantly higher tibial robusticity than females (Table 6).

[Figure 4 and Table 6 about here]

Table 7 presents the raw data used for EC analysis. ECs are very rare in the Mesolithic Sicilian sample, and no major changes (stage C) were recorded. Considering the very small Mesolithic Sicilian sample, the interpretation of difference with other prehistoric samples is tentative. When controlling for age (only 20-49 years old individuals), the overall frequency of EC in the Sicilian Mesolithic sample is very low (5.6\% (3/54)), close to the MUP and LUP ones (respectively 8.2 (8/98), and 7.3\%, (14/192)) and clearly inferior to the frequencies obtained for the Mesolithic (16.4\% (98/598)) and Neolithic (14.5\% (215/1479)) samples. Sicilian Mesolithic males and females do not differ in term of overall frequencies. Considering the laterality of the humeral lesions: Uzzo 1A (F), Uzzo 7 (M) and especially Uzzo 4A (I) tend to indicate a right side dominance whereas Molara 2 (M) tend to indicate a dominance for the left hand side. Results for asymmetry are similar: Uzzo 7 (M), Uzzo 4A (I) and Molara $2(\mathrm{M})$ are asymmetrical for at least one enthesis. This relatively clear pattern of laterality for ECs tends to place the Sicilian Mesolithic sample closer to Upper Paleolithic samples than to other Mesolithic and Neolithic ones (Table 8). Interestingly, Uzzo 7 (a male), displays a unilateral lesion at the right medial epicondyle, whereas none was recorded in females

One individual (Uzzo 5) displays slight bilateral EAEs (Table 7). The frequency of EAE in the Sicilian sample is $14.3 \%$ (1/7) is comparable to those seen in Late Mesolithic costal and estuarine sites (comprised between 9.9 and 19.4\%), below those of Mesolithic groups from the Iron Gates (40.1\%) and above those of European Neolithic groups (from 0.0 to 6.7\%) (see Villotte et al. 2014 for the raw data for each of the sites considered).

[Table 7 and 8 about here]

\section{Discussion}

The purpose of this paper was to make inferences on Mesolithic Sicilian activity patterns by integrating results from different types of activity-related skeletal morphologies (CSG, ECs, 
and EAE). We tested the hypothesis, based on isotopic and archaeozoological evidence (Tagliacozzo, 1993; Mannino and Thomas, 2009; Mannino et al., 2012) of a subsistence based on terrestrial hunting in continuity with earlier Pleistocene hunter-gatherers, and in contrast with other coastal and estuarine Mesolithic European groups. The comparison with other Late Pleistocene and Holocene prehistoric groups allowed for a characterization of the Sicilian group in terms of overall amount of subsistence-induced biomechanical stresses, upper limb asymmetry, and mobility, as well as possible differences in these parameters based on biological sex. We emphasize that the results should be discussed cautiously, given the small sample size involved in most comparisons. However, we collected the totality of the available data in a relatively small region, western Sicily, which is by far the Italian region with most Mesolithic human remains. By comparison, only three other Italian Mesolithic burials are published, and were unearthed in the northeastern Alps (Mezzocorona, Mondeval, and Vatte di Zambana; e.g. Sparacello et al., 2017). Therefore, the individuals analyzed here constitutes the best available assemblage to attempt inferences about Mesolithic lifestyle in this region of the Mediterranean.

Humeral biomechanical properties suggest that Sicilian Mesolithic males and females performed activities requiring a robust upper limb, as expected in a context of exploitation of high-cost/low-yield resources (Straus et al. 1981; Clark and Straus 1986; Stiner et al. 1999; Mussi 2001; Richards et al. 2001). In addition, and contrarily to what was observed in earlier periods, these activities did not result in a disproportionate involvement of the dominant limb. Paleolithic males show high values of humeral bilateral asymmetry, several times higher than what seen in modern sedentary individuals, and similar to that observed in professional tennis players (Jones et al., 1977; Trinkaus et al., 1994; Haapsalo et al., 2000; Sládek et al., 2016; Sparacello et al., 2017; Villotte et al., 2017). Upper limb asymmetry is generally linked to specific stressful activities that characterize the subsistence patterns of a population (Churchill, 1994; Trinkaus et al., 1994; Churchill et al, 1996, 2000; Marchi et al., 2006, 2011), as well as people practicing different sports (Trinkaus et al., 1994; Shaw and Stock, 2009b) or military activities (Sparacello et al., 2011, 2015). Churchill and colleagues (Churchill, 1993, 2002; Churchill et al., 2000; Schmitt et al., 2003) proposed that the Paleolithic activity that likely influenced asymmetry was the frequent use of throwing weapons during hunting, and especially long-distance hunting via atl-atl (Churchill, 2002; Churchill and Rhodes, 2009; Rhodes and Churchill, 2009). Antler and bone spear throwers have been unearthed in Solutrean to Upper Magdalenian layers (about 17,500 to 12,500 BP) 
in France, Switzerland, Germany, and Spain (Cattelain, 1997), although their invention was probably earlier (Shea, 2006). This activity is not only strenuous when performed during hunting, but requires continuous training for both strength and aim (Cattelain, 1997; Whittaker and Kamp, 2006). Overhead unilateral throwing generates levels of humeral torque as high as $48 \%$ of the total theoretical torsional rigidity of the humerus (Sabick et al., 2004), and can result in spiral "ball-thrower's fractures" to the humeral shaft (Ogawa and Yoshida, 1998). Accordingly, Paleolithic males share other traits with professional modern-day pitchers and javelin hurlers, such as high asymmetry in humeral retroversion (Rhodes and Churchill, 2009), and frequent unilateral medial humeral epicondyle enthesopathies (Villotte et al., 2010).

The significant decrease in the asymmetry of humeral robusticity observed in Sicilian Mesolithic males parallels previous studies based on classic osteometric measurements (Borgognini Tarli and Repetto, 1986), as well as the results obtained by Sládek et al (2016) in European skeletal series. Sládek et al (2016) propose that this change at the beginning of the Holocene could be attributed to a more frequent use of the bow-and-arrow over other types of projectile weapons, as demonstrated by archaeological evidence (Bergman, 1993; Churchill, 1993; Cattelain, 1997, 2006; Knecht, 1997). The cessation of the high torsional loading in the dominant arm due to throwing, as well as the increased loading on the non-dominant, holding arm would lead to a decrease in asymmetry, as suggested by previous studies on medieval military archers (Stirland, 1993; Knüsel, 2000; Rhodes and Knüsel, 2005). Although only the medieval longbow would probably generate significant bending moments on the upper limb (Rhodes and Knüsel, 2005), the frequent use of the bow use can produce mechanical stress leading to bursitis in the drawing shoulder and in the elbow of the holding arm (Lapostolle, 2004). However, the decrease in asymmetry alone is not sufficient to suggest that Sicilian Mesolithic people has a subsistence based on terrestrial hunting, possibly in forested environments where the use of bow over throwing spears is more appropriate (Cattelain, 1997). In fact, a number of activities linked to marine exploitation, including swimming, rowing, fishing, and food processing can involve the upper limb in a symmetric fashion (Weiss, 2003; Sparacello and Marchi, 2008; Shaw and Stock, 2009b).

Results from the lower limb allow for a direct comparison with European Mesolithic individuals whose subsistence was mainly based on coastal exploitation of marine resources (Holt, 2003). Although sample size is small, and results often do not reach statistical significance when reducing for multiple comparisons, Sicilian Mesolithic individuals, 
especially males, appear to have a more robust femur, and higher femoral shape indices, than their European counterparts. Femoral Ix/Iy is considered to be correlated with mobility patterns, and is normally referred to as a "mobility index" (review in Carlson and Marchi, 2014). Accordingly, highly mobile hunter-gatherers generally show higher values of femoral shape ratios than sedentary agriculturalists (e.g. Stock and Pfeiffer 2001; Holt 2003; Ruff et al. 2006a; Sládek at al. 2006a,b; Marchi 2008; Marchi et al. 2011; Sparacello et al. 2014), and athletes such as soccer players and runners show higher shape ratios than swimmers or sedentary controls (Macintosh and Stock, 2018). In addition, given similar mobility levels, groups settled in mountainous areas tend to have more robust femora (Ruff, 1999). Results from tibial CSG indicate high robusticity in males, and a lower shape index when compared with Paleolithic and European Mesolithic groups. This result may appear contradictory, given that both high tibial robusticity (Stock, 2006) and high tibial shape index (Ruff and Hayes, 1983; Holt, 2003, Marchi, 2008) have been associated with mobility levels. However, experimental evidence suggests that a combination of high tibial robusticity and low shape index can be caused by high mobility coupled with the medio-lateral bending loads generated by frequent swerving and/or traversing rugged terrain (Shaw and Stock 2009; Marchi and Shaw 2011). Among prehistoric groups, similarly leg loading patterns may have been caused by mobility in highly uneven and mountainous terrains (Marchi et al. 2011; Sparacello et al., 2014, 2018; Higgins 2014). While Sicilian Mesolithic people were possibly less mobile than Upper Paleolithic hunters (Borgognini Tarli and Repetto, 1986), our results (especially for males) tend to set them apart from the European Mesolithic sample in having a stronger component of mobility in the inland. This would be compatible with a more important exploitation of terrestrial resources, as indicated by isotopic analyses (Mannino et al, 2011a,b; Mannino et al., 2012). Unfortunately, no data on fibular robusticity and tibio-fibular ratio is available for European Mesolithic people, which could further inform on mediolateral bending loads correlated to traversing uneven terrains (Sparacello et al., 2014; Hagihara and Nara, 2016, 2018).

The main factor affecting the frequency of ECs remains age. Unfortunately, obtaining an ageat-death estimation has been possible only for part of the individuals in the Mesolithic sample. When controlled for age (i.e. considering only the adult individuals that died before 50 years old; see Villotte 2009; Villotte et al. 2010a, b), the overall frequency of ECs is very low, especially when compared to Late Mesolithic and Neolithic samples. This seems to 
indicate a relatively lower overall amount of biomechanical stresses for the Sicilian Mesolithic sample compared to later prehistoric groups.

Considering the upper limb, the study of ECs and CSG properties provides contrasting results. ECs indicate a relatively clear importance of unimanual activities, whereas CSG properties provide low values of asymmetry, which in a context of high robusticity can be interpreted as an indicator of bimanual activities (see above). Furthermore, there is no consistent correspondence between laterality as described by ECs and CSG, and the individual with a unilateral lesion at the right medial epicondyle (Uzzo 7) is the least asymmetric in the sample when considering CSG.

Both CSG and ECs have been extensively used to infer activity patterns in bioarchaeological samples, although numerous studies have warned against simplistic interpretations of the results, given the number of concomitant factors influencing bone mechanical competence, entheseal appearance, and other "markers of activities” (Pearson and Lieberman, 2004; Meyer et al., 2011; Jurmain et al., 2012). Few studies have been explicitly focusing on the relationship between the types of markers analyzed here (Niinimäki, 2012; Niinimäki and Baiges Sotos, 2013; Ibáñez-Gimeno et al., 2013), and at best have found a general correspondence between the two (e.g. Lieverse et al., 2011). More detailed tests between ECs scores and CSG values have failed to provide a consistent association (Niinimäki, 2012; Michopoulou et al., 2017; Nikita et al., 2019). The small sample size, and the fact that subsamples based on variables often include different assortments of individuals, may explain in part the substantial discrepancy found here. In addition, the information provided by CSG and ECs properties may differ in a substantial way. The "baseline" total area and thickness of diaphyses, which determine CSG robusticity, is the result of the 'mechanical environment' affecting body dimensions and activity levels during the pre- and peri-pubertal periods (Lazenby, 1990; Pearson and Lieberman, 2004). Although imperfect, standardization by body size is commonly employed in CSG studies (Ruff, 200). Senescence does influence CSG properties, due to continued periosteal apposition to mechanically compensate for medullary expansion (especially in males; Martin and Atkinson, 1977; Ruff and Hayes, 1988). This generally plays a minor role in prehistoric samples: in our study, only the female Oriente B has an estimated age > 50 years old, and her CSG robusticity does not appear particularly high. In addition, it is generally assumed that bioarchaeological samples are mostly composed by individuals that participated to activities typical of their subsistence regimes early in life, 
and died before the onset of senescence, hence CSG is mostly a reflection of activity early in life.

In contrast, for ECs, the whole correlation with activity patterns is questioned once age and body size are taken into account (e.g. Alvares Cardoso and Henderson, 2010; Nikita et al., 2019). Compared to CSG, the ECs “baseline” early in life is 0, and lesions must be acquired throughout the lifetime. Moreover, ECs do not appear automatically with the specific or repetitive use of a muscle, i.e. their absence does not mean that a certain muscle or limb was not involved in strenuous habitual activities. Therefore, there may be little justification for expecting a general correspondence between ECs scores and CSG robusticity; they may inform on different processes and may or may not correlate with each other depending on the individual's history. However, it is possible that specific entheseal changes, and especially their asymmetry, may be indicative of certain habitual activities, which may also be detected by biomechanical analysis. In this complex scenario, further research is necessary. Finite elements analysis may inform on the areas of bone that sustain most stress, and may therefore more likely to show structural adaptations and alterations (e.g. Vickerton et al., 2014). Multivariate and 3D analysis of overall entheseal morphology and shape may correlate better with biomechanical parameters or muscle use (e.g. Karakostis et al., 2017, 2018, 2019a,b). Future studies will certainly take advantage of the data collection of 3D models conducted here, making sharing raw data and collaborations easier than in the past.

In the Sicilian Mesolithic sample, only one case of bilateral EAE (grade 1) has been recorded. It is always complicated to discuss low frequencies of EAEs, especially in a small sample (Villotte and Knüsel 2016). In addition to frequent contact with cold water, infection, eczema, trauma, or other pathological conditions affecting the normal homeostasis of the external ear canal may cause an auditory exostosis in a very small number of individuals (Di Bartolomeo et al., 1991; Fowler and Osmun, 1942), and Uzzo 5 may represent one of these cases. Furthermore, the absence of EAE does not exclude aquatic activities, as individuals may protect their ears, young adults frequently in contact with cold water may have died before developing the condition, and some individuals do not develop EAE, even if they are frequently engaged in aquatic activities during their whole life. A great part of the Sicilian Mesolithic individuals are young adults, and may have not lived long enough to develop EAEs. It is tempting to consider the presence of bilateral EAEs in one individual as an indicator of aquatic activities practiced by these groups, but if this is the case, these aquatic activities were likely not a preponderant part of their daily life. Indeed, in populations for 
which isotopic data indicated a strong reliance on aquatic resources, EAEs tend to be very frequent and the occlusion of the ear canal is sometimes important (i.e.; grades 2 or 3) (e.g. Villotte et al. 2014, Crow et al. 2010, Kusaka et al. 2010), which is not the case here. Our results, even if they have to be taken with caution considering the sample size, seem compatible with those from isotopic analyses previously carried out on these individuals, indicating at least for the diet, not a strong relationship with the aquatic environment.

\section{Conclusions}

We tested, using cross-sectional geometry, entheseal changes, and presence of external auditory meatus exostosis the hypothesis - bases on isotopic and zooarchaeological evidence - that in Sicily, marine food become important only in the late Mesolithic, while in the earlier phases terrestrial resources were predominantly exploited, in substantial continuity with previous Epigravettian hunters. Results indeed show similarities in the general frequency of entheseal changes - a rough proxy for overall activity - with Late Pleistocene hunters, in contrast with Mesolithic coastal foragers or Neolithic herders/farmers. Yet, cross-sectional geometry suggests that this possible continuity in the type of resources exploited was nevertheless accompanied by a substantial behavioral change, and in particular the abandonment of the throwing technology, possibly in favor of new tools such as traps and the bow and arrow. In fact, this study confirms that the dramatic decrease in humeral bilateral asymmetry documented at a European level with the Pleistocene-Holocene transition can be found also in the Mediterranean at a regional level. Results for the lower limb are less clear, probably due to the small sample size, but appear compatible with a certain degree of terrestrial mobility in a rugged environment. The presence of EAE suggests that activities related to water were present but not common; however, their prominence is difficult to determine given the small sample size, and given that absence of EAE does not exclude contact with water.

The pattern of information provided by the proxies for activity used here is complex and partially contrasting, but has the potential to integrate and enrich archaeological methods and biochemical approaches. This study corroborates a varied scenario of continuity and discontinuity in subsistence at the Pleistocene-Holocene transition, and highlights the importance of a regional bioarchaeological approach of human biological and behavioral adaptations. 


\section{Acknowledgements}

The Authors thank the Polo regionale di Palermo per i Parchi e i Musei Archeologici, the Museo Salinas, and the Museo di Geologia "G.G. Gemmellaro" for the permission to conduct this study. Thanks to Rosaria Di Salvo, Carolina Di Patti, Carolina D’Arpa, and the staff of the museums.

For access to the Ligurian skeletal material, thanks to the Soprintendenza Archeologia, Belle Arti e Paesaggio per la città metropolitana di Genova e le provincie di Imperia, La Spezia e Savona, in particular the OfficersMarta Conventi, Elisabetta Starnini, Nico Radi, and Stefano Costa. Thanks to the Director of the Museo di Archeologia Ligure, Patrizia Garibaldi, for granting access to the collections owned by the Comune di Genova, and to Guido Rossi and Irene Molinari. Thanks to the Director of the Museo di Storia Naturale - Sezione di Antropologia e Etnologia, Università degli Studi di Firenze, Monica Zavattaro, and to Jacopo Moggi Cecchi. Thanks to the Director of the Museo Archeologico del Finale, Daniele Arobba, and to the Curator Andrea De Pascale. We would like to also thank for collaboration to data collection: Irene Dori, Chiara Panelli, Stefano Rossi, Roberto Maggi, Vincenzo Formicola, Paolo Biagi, Giovanni Murialdo, Elisa Bianchi, Simona Mordeglia, Walter Siciliano, Gwenaëlle Goude, Giovanna Stefania, Luca Bachechi, Chiara Bullo, and Brunetto Chiarelli.

During the data collection and analysis, VSS was funded by French State in the framework of the” Investments for the future” Program, IdEx Bordeaux, reference ANR-10-IDEX-03-02, by the Marie-Curie European Union COFUND/Durham Junior Research Fellowship [under EU grant agreement number 267209], and by the Wolfson Institute for Health and Wellbeing, Durham,UK

\section{Literature Cited}

Albert AM, Maples WR (1995) Stages of epiphyseal union for thoracic and lumbar vertebral centra as a method of age determination for teenage and young adult skeletons. J Forensic Sci 40:623-633.

Alciati G, Pesce Delfino V, Vacca E (2005) Catalogue of Italian fossil human remains from the Palaeolithic to the Mesolithic. J Anthropol Sci (suppl) 84:1-184. 
Alves Cardoso FA, Henderson CY (2010) Enthesopathy formation in the humerus: data from known age-at-death and known occupation skeletal collections. Am J Phys Anthropol 141:550-560.

Bailey GN, Flemming NC (2008) Archaeology of the continental shelf: marine resources, submerged landscapes and underwater archaeology. Quat Sci Rev 27:2153-2165.

Bergman CA (1993) The development of the bow in Western Europe: A technological and functional perspective. Archaeol Papers Am Anthropol Assoc 4:95-105.

Bocherens H et al (2015) Reconstruction of the Gravettian food-web at Předmostí I using multi-isotopic tracking (13C, 15N, 34S) of bone collagen. Quat Int 359:211-228

Bogucki P (2001) Recent research on early farming in central Europe. Doc Praeh 28:85-97. https://doi.org/10.4312/dp.28.6

Borgognini Tarli SM (1976) Studio antropologico di un cranio mesolitico rinvenuto nella grotta della Molara (Palermo-Sicilia). Arch Antropol Etnol 106:193-228.

Borgognini Tarli SM (1980) Inquadramento, nel contesto del Mesolitico italiano, degli scheletri provenienti da una sepoltura duplice nella grotta dell’Uzzo (Trapani). Antropol Contemp 3:381-393.

Borgognini Tarli SM, Repetto E (1986) Skeletal indicators of subsistence patterns and activitty régime in the Mesolithic sample from Grotta dell’Uzzo (Trapani, Sicily): a case study. J Hum Evol 1(4):331-352.

Borgognini Tarli SM, Canci A, Piperno M, Repetto E (1993) Dati archeologici e antropologici sulle sepolture mesolitiche della Grotta dell’Uzzo (Trapani). Bull Paletnol It 84:85-179.

Bruzek J (2002) A method for visual determination of sex using the human hip bone. Am J Phys Anthropol 117:157-168.

Bruzek J, Santos F, Dutailly B, Murail P, Cunha E (2017) Validation and reliability of the sex estimation of the human os coxae using freely available DSP2 software for bioarchaeology and forensic anthropology. Am J Phys Anthropol 64(2):440-449.

Canci A, Minozzi S, Repetto E, Borgognini Tarli SM (1995) Mesolithic skeletal remains from Grotta della Molara (Palermo, Sicily). Riv Antropol 73:237-254. 
Carlson KJ, Marchi D (2014) Introduction: towards refining the concept of mobility. In: Carlson KJ, Marchi D (eds) Reconstructing mobility. Environmental, behavioural, and morphological determinants. Springer, New York, pp 1-12.

Cassoli PF, Tagliacozzo A (1994) I macromammiferi dei livelli tardopleistocenici delle Arene Candide (Savona, Liguria): considerazioni paleontologiche e archaeozoologiche. Quaternaria Nova 4:101-262.

Cattelain P (1997) Hunting during the Upper Paleolithic Bow Spearthrower or Both? In: Knecht H (ed) Projectile Technology. Springer, New York, pp 213-240.

Cattelain P (2006) Apparition et évolution de l'arc et des pointes de flèches dans la préhistoire européenne (Paléo-, Méso-, Néolithique). In: Bellintani P (ed) Catene Operative dell’arco Preistorico. Giunta della Provincia Autonoma di Trento, Trento, pp 45-66.

Churchill SE (1993) Weapon technology, prey size selection, and hunting methods in modern hunter-gatherers: implications for hunting in the Paleolithic and Mesolithic. In: Peterkin GL, Bricker HM, Mellars P (eds) Hunting and animal exploitation in the Late Paleolithic and Mesolithic Europe. Archaeol Papers Am Anthropol Assoc 4:11-24. doi.org/10.1525/ap3a.1993.4.1.11

Churchill SE (1994) Human Upper Body Evolution in the Eurasian Later Pleistocene. Dissertation, University of New Mexico.

Churchill SE (2002) Of assegais and bayonets: reconstructing prehistoric spear use. Evol Anthropol 11:185-186.

Churchill SE, Weaver AH, Niewoehner WA (1996) Late Pleistocene human technological and subsistence behavior: functional interpretations of upper limb morphology. Quaternaria Nova 6:413-447.

Churchill SE, Formicola V (1997) A case of marked bilateral asymmetry in the upper limbs of an upper Paleolithic male from Barma Grande (Liguria), Italy. Int J Osteoarch 7:18-38.

Churchill SE, Formicola V, Holliday TW, Holt BM, Schumann BA (2000) The Upper Paleolithic population of Europe in an evolutionary perspective. In: Roebroeks W, Mussi M, Svoboda J, Fennema K (eds) Hunters of the Golden Age: the Mid Upper Paleolithic of Eurasia (30.000-20.000 bp). Leiden University Press, Leiden, pp 31-57. 
Churchill SE, Rhodes J (2009) The evolution of the human capacity for "killing at a distance": the human fossil evidence for the evolution of projectile weaponry. In: Hublin J-J, Richards MP (eds) The evolution of hominin diets. Springer, New York, pp 201-210.

Clark PU, AS Dyke J D Shakun AE, Carlson J, Clark B, Wohlfarth J X Mitrovica, S W Hostetler, AM McCabe (2009) The Last Glacial Maximum. Science 325(5941):710-714 doi:10.1126/science.1172873.

Clark GA, Straus LG (1986) Synthesis and conclusions part I: Upper Paleolithic and Mesolithic hunter-gatherer subsistence in northern Spain. In: Straus LG, Clark GA (eds) La Riera Cave: Stone Age hunter-gatherer adaptations in northern Spain. Tempe: Arizona State University anthropological research papers 36:351-365.

Cooper A, Tong R, Neil R, Owens D, Tomkinson A (2010) External auditory canal exostoses in white water kayakers. Br J Sports Med 44:144-147.

Craig OE, Biazzo M, Colonese AC, Di Giuseppe Z, Martinez-Labarga C, Lo Vetro D, Lelli R, Martini F, Rickards O (2010) Stable isotope analysis of Late Upper Palaeolithic human and faunal remains from Grotta del Romito (Cosenza), Italy. J Archaeol Sci 37:2504-2512. Cristiani E, Radini A, Borić D, Robson HK, Caricola I, Carra M, Mutri G, Oxilia G, Zupancich A, Šlaus M, Vujević D (2018) Dental calculus and isotopes provide direct evidence of fish and plant consumption in Mesolithic Mediterranean. Sci Rep 8(1):8147. doi: 10.1038/s41598-018-26045-9

Crowe F, Sperduti A, O'Connell TC, Craig OE, Kirsanow K, Germoni P, Macchiarelli R, Garnsey P, Bondioli L (2010) Water-related occupations and diet in two Roman coastal communities (Italy, first to third century AD): correlation between stable carbon and nitrogen isotope values and auricular exostosis prevalence. Am J Phys Anthropol 142:355-366.

Di Bartolomeo J, Paparella M, Meyerhoff W (1991) Cysts and tumors of the external ear. In: Shumrick D, Gluckman J, Meyerhoff W (eds) Otolaryngology, 3rd ed., Vol. 2. Philadelphia: Saunders, pp 1243-1258.

Diniz M (2016) Assessing hunter-gatherer subsistence practices and cultural landscapes in Southern Portugal during the Final Mesolithic. Archéologie des chasseurs-cueilleurs maritimes de la fonction des habitats à l'organisation de l'espace littoral. In : Dupont C, 
Marchand G (eds) Actes de la séance de la Société préhistorique française de Rennes, (10-11 avril 2014). Paris, Société Préhistorique Française 6:145-158.

Di Salvo R, Mannino G, Mannino MA, Schimmenti V, Sineo L, Thomas KD (2012) Le sepolture della Grotta d'Oriente (Favignana). Atti della XLI Riunione Scientifica dell’Istituto Italiano di Preistoria e Protostoria. Firenze: Istituto Italiano di Preistoria e Protostoria, pp $341-351$.

Di Salvo R, Mannino M, Schimmenti V, Sineo L, Thomas KD (2012b) Nuovi dati sulle sepolture della Grotta dell’Uzzo. Atti della XLI Riunione Scientifica dell’Istituto Italiano di Preistoria e Protostoria. Firenze: Istituto Italiano di Preistoria e Protostoria, pp 461-470.

Drucker DG, Naito YI, Péan S, Prat S, Crépin L, Chikaraishi Y, Ohkouchi N, Puaud S, Lázničková-Galetová M, Patou-Mathis M, Yanevich A, Bocheren H (2017) Isotopic analyses suggest mammoth and plant in the diet of the oldest anatomically modern humans from far southeast Europe. Sci Rep doi: 10.1038/s41598-017-07065-3

Fa DA (2008) Effects of tidal amplitude on intertidal resource availability and dispersal pressure in prehistoric human coastal populations: the Mediterranean-Atlantic transition. Quat Sci Rev 27:2194-2209.

Fontana F, Govoni L, Guerreschi A, Padoanello S, Siviero A, Thun Hohenstein U, Ziggiotti S (2009) L’occupazione sauveterriana di Mondeval da Sora de Sora 1, settore I (San Vito di Cadore, Belluno) in bilico tra accampamento residenziale e campo da caccia. Preist Alp 44:207-226.

Fontana F, Visentin D (2016) Between the Venetian Alps and the Emilian Apennines (Northern Italy): highland vs. lowland occupation in the early Mesolithic. Quat Int 423:266278. doi:10.1016/j.quaint. 2015.12.014.

Fowler EP, Osmun PM (1942) New bone growth due to cold water in the ears, Arch Otolaryngol Head Neck Surg 36:455-466.

Gamble C (1986) The Paleolithic settlement of Europe. Cambridge: Cambridge University Press.

Garcia-Guixe E, Richards MP, Suburà E (2006) Palaeodiets of Humans and Fauna at the Spanish Mesolithic Site of El Collado. Curr Anthropol 47:549-556. 
Garcia-Guixe E, Martínez-Moreno J, Mora R, Núnez M, Richards MP (2009) Stable isotope analysis of human and animal remains from the Late Upper Palaeolithic site of Balma Guilanya, southeastern Pre-Pyrenees, Spain. J Archaeol Sci 36:1018-1026.

Gazzoni V, Goude G, Herrscher E, Guerreschi A, Antonioli F, Fontana F (2013) Late Upper Palaeolithic human diet: first stable isotope evidence from Riparo Tagliente (Verona, Italy). Bull Mém Soc Anthropol Paris 25:103-117.

Germonpré M, Sablin M, Khlopachev GA, Grigorieva GV (2008) Possible evidence of mammoth hunting during the Epigravettian at Yudinovo, Russian Plain. J Anthropol Archaeol 27:475-492.

Goude G, Willmes M, Wood R, Courtaud P, Leandri F, Cesari J, Grün R (2017) New Insights into Mesolithic Human Diet in the Mediterranean from Stable Isotope Analysis: The Sites of Campu Stefanu and Torre d’Aquila, Corsica. Intern J of Osteoarch 27(4):707-714.

Gowlett JAJ, Hedges REM, Law IA, Perry C (1987) Radiocarbon dates from the Oxford AMS system: archaeometry datelist 5. Archaeometry 29:125-155.

Grine FE, Jungers WL, Tobias PV, Pearson OM (1995) Fossil Homo femur from Berg Aukas, northern Namibia. Am J Phys Anthropol 26:67-78.

Haapasalo H, Kontulainen S, Sievanen H, Kannus P, Jarvinen M, Vuori I (2000) Exerciseinduced bone gain is due to enlargement in bone size without a change in volumetric bone density: a peripheral quantitative computed tomography study of the upper arms of male tennis players. Bone 27:351-357.

Hagihara Y, Nara T (2016) Morphological features of the fibula in Jomon hunter-gatherers from the shell mounds of Pacific coastal area Am J Phys Anthropol 160:708-718.

Hagihara Y, Nara T (2018) Diaphyseal cross-sectional geometry of the metatarsal bones in the Jomon population Am J Phys Anthropol doi: 10.1002/ajpa.23463

Higgins RW (2014) The effects of terrain on long bone robusticity and cross-sectional shape in lower limb bones of bovids, Neanderthals, and Upper Paleolithic modern humans. In: Carlson K, Marchi D (eds) Reconstructing mobility: environmental, behavioral, and morphological determinants. Springer, New York, pp 227-252.

Holt BM (1999) Mobility in Upper Paleolithic and Mesolithic Europe: biomechanical evidence from the lower limb. Dissertation, University of Missouri. 
Holt BM (2003) Mobility in Upper Paleolithic and Mesolithic Europe: evidence from the lower limb. Am J Phys Anthropol 122:200-215.

Holt BM, Formicola V (2008) Hunters of the Ice Age: the biology of Upper Paleolithic people. Yearbook of Phys Anthropol 51:70-99.

Holt BM, Mussi M, Churchill SE, Formicola V (2000) Biological and cultural trends in Upper Palaeolithic Europe. Riv Antropol 78:179-182.

Hurst W, Bailey M, Hurst B (2004) Prevalence of external auditory canal exostoses in Australian surfboard riders. J Laryngol Otol 118:348-351.

Ibáñez-Gimeno P, Galtés I, Jordana X, Fiorin E, Manyosa J, Malgosa A (2013) Entheseal Changes and Functional Implications of the Humeral Medial Epicondyle. Int J Osteoarchaeol 23:211-220.

Jacobi R, Higham T (2009) The early Lateglacial re-colonization of Britain: new radiocarbon evidence from Gough's Cave, southwest England. Quat Sci Rev 28:1895-1913.

Jones HH, Priest JD, Hayes WC, Tichenor CC, Nagel DA (1977) Humeral hypertrophy in response to exercise. J Bone Joint Surg Am 59:204-208.

Jurmain R, Alves Cardoso F, Henderson C, Villotte S (2012) Bioarchaeology's Holy Grail: The reconstruction of activity. In: Grauer AL (ed) A Companion to Paleopathology. WileyBlackell, New York, pp. 531-552.

Karakostis, F.A., Hotz, G., Scherf, H., Wahl, J., Harvati, K. 2017. Occupational manual activity is reflected on the patterns among hand entheses. Am J Phys Anthropol 164:30-40.

Karakostis FA, Hotz G, Scherf H, Wahl J, Harvati K (2018) A repeatable geometric morphometric approach to the analysis of hand entheseal three-dimensional form. Am J Phys Anthropol 166:246-260.

Karakostis FA, Jeffery N, Harvati K (2019a) Experimental proof that multivariate patterns among muscle attachments (entheses) can reflect repetitive muscle use. Nat Sci Rep 9:16577. Karakostis FA, Vlachodimitropoulos D, Piagkou M, Scherf H, Harvati K, Moraitis K (2019b) Is Bone Elevation in Hand Muscle Attachments Associated with Biomechanical Stress? A Histological Approach to an Anthropological Question. Anat Rec 302:1093-1103. doi:10.1002/ar.23984 
Kennedy GE (1986) The relationship between auditory exostosis and cold water: a latitudinal analysis. Am J Phys Anthropol 71:401-415.

Knecht H (1997) The history and development of projectile technology research. In: Knecht H (ed) Projectile technology. Plenum Press, New York, pp 3-35.

Knüsel CJ (2000) Bone adaptation and its relationship to physical activity in the past. In: Cox M, Mays SA (eds) Human osteology in archeology and forensic science. Greenwich Medical Media, London, pp 381-401.

Kusaka S, Hyodo F, Yumoto T, Nakatsukasa M (2010) Carbon and nitrogen stable isotope analysis on the diet of Jomon populations from two coastal regions of Japan. J Archaeol Sci 37:1968-1977

Lapostolle JC (2004) Elbow pathologies in archery. In: Ergen E, Hibner K (eds) Sports Medicine and Science in Archery. FITA, Medical Committee, Lausanne, pp 70-81.

Lightfoot E, Boneva B, Miracle PT, Šlaus M, O’Connell TC (2011) Exploring the Mesolithic and Neolithic transition in Croatia through isotopic investigations. Antiquity 85:73-86. Lowe JJ, Walker MJC (2000) Radiocarbon dating the Last Glacial-Interglacial Transition (ca14-914C ka BP) in terrestrial and marine records: the need for new quality assurance protocols. Radiocarbon 42:53-68.

Lazenby RA (1990) Continuing periosteal apposition II: the significance of peak bone mass, strain equilibrium, and age related activity differentials for mechanical compensation in human tubular bones. Am J Phys Anthropol 82:473-484.

Lieverse AR, Stock JT, Katzemberg MA, et al (2011) The bioarcheology of habitual activity and dietary change in the Siberian Middle Holocene. In: Pinhasi R, Stock J (eds) Human bioarchaeology of the Transition to Agriculture. Wiley-Liss, New York, pp 265-291. Macintosh AA, Davies TG, Ryan TM, Shaw CN, Stock JT (2013) Periosteal versus true cross-sectional geometry: a comparison along humeral, femoral, and tibial diaphysis. Am J Phys Anthropol 150:442-452.

Macintosh AA, Stock JT (2018) Intensive terrestrial or marine locomotor strategies are associated with inter- and intra-limb bone functional adaptation in living female athletes. Am J Phys Anthropol 168:566-581. 
Magri D (2008) Lineamenti della vegetazione tardoglaciale in Italia peninsulare e in Sicilia. In: Mussi M (ed) Il Tardiglaciale in Italia. Lavori in corso. British Archaeological Reports International Series 2320. Archaeopress, Oxford.

Mangerud J, Andersen ST, Berglund BE, Donner JJ (1974) Quaternary stratigraphy of Norden, a proposal for terminology and classification. Boreas 3:109-128.

Mannino MA, Thomas KD (2001) Intensive Mesolithic Exploitation of Coastal resources? Evidence from a Shell Deposit on the Isle of Portland (Southern England) for the Impact of human Foraging on Populations of Intertidal Rocky Shore Molluscs. J Archaeol Sci 28(10):1101-1114.

Mannino MA, Thomas KD (2009) Current research on prehistoric human coastal ecology: Late Pleistocene and Early Holocene hunter-gatherer transitions in north-west Sicily. In: McCartan S, Schulting R, Warren G, Woodman P (eds) Mesolithic Horizons. Oxbow Books, Oxford, pp. 140-145.

Mannino MA, Thomas KD, Leng MJ, Di Salvo R, Richards MP (2011a) Stuck to the shore? Investigating prehistoric hunter-gatherer subsistence, mobility and territoriality in a Mediterranean coastal landscape through isotope analyses on marine mollusc shell carbonates and human bone collagen. Quat Int 244:88-104.

Mannino M, Di Salvo R, Schimmenti V, Di Patti C, Incarbona A, Sineo L, Richards MP (2011b) Upper Palaeolithic hunter-gatherer subsistence in Mediterranean coastal environments: an isotopic study of the diets of the earliest directly-dated humans from Sicily. J Archaeol Sci 38:3094-3100.

Mannino MA, Catalano G, Talamo S, Mannino G, Di Salvo R et al (2012) Origin and Diet of the Prehistoric Hunter-Gatherers on the Mediterranean Island of Favignana (Egadi Islands, Sicily). PLoS ONE 7(11):e49802.

Mannino MA, Talamo S, Tagliacozzo A, Fiore I, Nehlich O, Piperno M, Tusa S, Collina C, Di Salvo R, Schimmenti V, Richards MP (2015) Climate-driven environmental changes around 8,200 years ago favoured increases in cetacean strandings and Mediterranean huntergatherers exploited them. Nature Sci Rep 5:16288 DOI: 10.1038/srep16288

Marchand G, Dupont C, Delhon C, Desse-Berset N, Gruet Y, Laforge M, Le Bannier J-C, Netter C, Nukushina D, Onfray M, Querre G, Quesnel L, Schulting R, Stephan P, Tresset A 
(2016) Retour à Beg-er-Vil. Nouvelles approches des chasseurs-cueilleurs maritimes de France atlantique. Archéologie des chasseurs-cueilleurs maritimes. De la fonction des habitats à l'organisation de l'espace littoral. Actes de la séance de la Société Préhistorique Française de Rennes, 10-11 avril 2014. G. Marchand and C. Dupont. Paris, Société Préhistorique Française 6:283-319.

Marchi D (2008) Relationships between lower limb cross-sectional geometry and mobility: The case of a Neolithic sample from Italy. Am J Phys Anthropol 137:188-200.

Marchi D, Shaw CN (2011) Variation in fibular robusticity reflects variation in mobility patterns. J Hum Evol 61:609-616.

Marchi D, Sparacello VS, Holt BM, Formicola V (2006) Biomechanical approach to the reconstruction of activity patterns in Neolithic Western Liguria, Italy. Am J Phys Anthropol 131:447-455.

Marchi D, Sparacello VS, Shaw CN (2011) Mobility and lower limb robusticity of a pastoralist Neolithic population from North-Western Italy. In: Pinhasi R, Stock JY (eds) Human bioarchaeology of the Transition to Agriculture. John Wiley \& Sons, New York, pp 317-346.

Martin RB, Atkinson PJ. (1977) Age and sex-related changes in the structure and strength of the human femoral shaft. J Biomech 10:223-231.

Matiegka J (1938). Homo předmostensis. Fosilní člověk z Předmostí na Moravě I. Nákladem Česká Akademie Věd a Umĕní, Prague.

Matiegka J (1938). Homo předmostensis. Fosilní člověk z Předmostí na Moravě II. Ostatní Č́sti Kostrové. Česká Akademie Věd a Umění, Prague.

McHenry HM (1992) Body size and proportions in early Hominids. Am J Phys Anthropol 87:407-431.

Meyer C, Nicklisch N, Held P, Fritsch B, Alt KW (2011) Tracing patterns of activity in the human skeleton: An overview of methods, problems, and limits of interpretation. J Comp Hum Biol 62:202-217.

Michopoulou E, Nikita E, Henderson CY (2017) A test of the effectiveness of the Coimbra method in capturing activity-induced entheseal changes. Int J Osteoarch 27:409-417. 
Moore AMT (2014) Post-glacial transformations among hunter-gatherer societies in the Mediterranean and western Asia. In: Cummings V, Jordan P, Zvelebil M (eds) The Oxford handbook of the archaeology and anthropology of hunter-gatherers. Oxford Handbooks Online, Oxford, pp 456-478.

Murail P, Bruzek J, Braga J (1999) A new approach to sexual diagnosis in past populations, Practical adjustments from Van Vark’s procedure. Int J Osteoarchaeol 9:39-53.

Murail P, Bruzek J, Houët, Cunha E (2005) DSP: A tool for probabilistic sex diagnosis using worldwide variability in hip-bone measurements. Bull Mém Soc Anthropol Paris 17(34):161-176.

Mussi M, Roebroeks W, Svoboda J (2000) Introduction. In: Roebroeks W, Mussi M, Svoboda J, Fennema K (eds) Hunters of the Golden Age: the Mid Upper Palaeolithic of Eurasia (30.000-20.000 bp). Leiden, Leiden University Press, pp 1-12.

Mussi M (2001) Earliest Italy: An Overview of the Italian Paleolithic and Mesolithic. Kluwer and Plenum, New York.

Nagurka ML, Hayes WC (1980) An interactive graphics package for calculating crosssectional properties of complex shapes. J Biomech 13:59-64.

Niinimäki S (2012) The relationship between musculoskeletal stress markers and biomechanical properties of the humeral diaphysis. Am J Phys Anthropol 147:618-628.

Niinimäki S, Baiges Sotos L (2013) The Relationship Between Intensity of Physical Activity and Entheseal Changes on the Lower Limb. Int J Osteoarchaeol 23:221-228.

Nikita E, Xanthopoulou P, Bertsatos A, Chovalopoulou M-E, Hafez I (2019) A threedimensional digital microscopic investigation of entheseal changes as skeletal activity markers. Am J Phys Anthropol DOI: 10.1002/ajpa.23850.

O’Neill MC, Ruff CB (2004) Estimating human long bone cross-sectional geometric properties: a comparison of noninvasive methods. J Hum Evol 47:221-235.

Ogawa K, Yoshida A (1998) Throwing fracture of the humeral shaft: an analysis of 90 patients. Am J Sports Med 26:242-246. 
Owings Webb PA, Suchey JM (1985) Epiphyseal union of the anterior iliac crest and medial clavicle in a modern multiracial sample of American males and females. Am J Phys Anthropol 68:457-466.

Paine C, O’Connell TC, Miracle PT (2009) Stable isotopic reconstruction of early Mesolithic diet at Pupicina Cave. In: McCartan S, Schulting R, Warren G, Woodman P (eds) Mesolithic horizons. Oxbow, Oxford, pp 210-216.

Pearson OM (1997) Postcranial morphology and the origin of modern humans. PhD Dissertation, State University of New York at Stony Brook.

Pearson OM, Lieberman DE (2004) The aging of Wolff's 'Law': ontogeny and response to mechanical loading in cortical bone. Am J Phys Anthropol 47:63-99.

Pearson OM, Sparacello VS (2017) Behavioral differences between near eastern Neandertals and early modern humans from Skhul and Qafzeh: an assessment based on comparative samples of Holocene humans. In: Hovers E, Marom A (eds) Human Paleontology and Prehistory. Contributions in Honor of Yoel Rak. Springer, New York, pp 175-186.

Ravazzi C, Peresani M, Pini R, Vescovi E (2007) Il Tardoglaciale nelle Alpi italiane e in Pianura Padana. Evoluzione stratigrafica, storia della vegetazione e del popolamento antropico. It J Quat Sci 20:163-184.

Rhodes JA, Churchill SE (2009) Throwing in the Middle and Upper Paleolithic: inferences from an analysis of humeral retroversion. J Hum Evol 56:1-10.

Rhodes JA, Knüsel CJ (2005) Activity-related skeletal change in medieval humeri: crosssectional and architectural alterations. Am J Phys Anthropol 128:536-546.

Richards M P, Mellars P (1998) Stable isotopes and the seasonality of the Oronsay middens. Antiquity 72:178-84.

Richards MP (2009) Stable Isotope Evidence for European Upper Paleolithic Human Diets. In: Hublin JJ, Richards MP (eds) The Evolution of Hominin Diets. Vertebrate Paleobiology and Paleoanthropology. Springer, Dordrecht.

Richards MP, Jacobi R, Currant A, Stringer C, Hedges REM (2000) Gough's Cave and Sun Hole Cave human stable isotope values indicate a high animal protein diet in the British Upper Palaeolithic. J Archaeol Sci 27:1-3. 
Richards MP, Pettitt PB, Stiner MC, Trinkaus E (2001) Stable isotope evidence for increasing dietary breadth in the European mid-Upper Paleolithic. PNAS 98 (11):6528-6532.

Richards MP, Jacobi R, Cook J, Pettitt PB, Stringer CB (2005) Isotope evidence for the intensive use of marine foods by Late Upper Palaeolithic humans. J Hum Evol 49:390-394.

Richards MP, Karavanić, Pettitt P, Miracle P (2015) Isotope and faunal evidence for high levels of freshwater fish consumption by Late Glacial humans at the Late Upper Palaeolithic site of Šandalja II, Istria, Croatia. J Archaeol Sci 61:204-212.

Ruff CB (1995) Biomechanics of the hip and birth in early Homo. Am J Phys Anthropol 98:527-574.

Ruff CB (1999) Skeletal structure and behavioral patterns of prehistoric Great Basin populations. In: Hemphill BE, Larsen CS (eds) Prehistoric lifeways in the Great Basin wetlands: bioarchaeological reconstruction and interpretation. University of Utah Press, Salt Lake City, pp 290-320.

Ruff CB (2000) Body size, body shape, and long bone strength in modern humans. J Hum Evol 38:269-290.

Ruff CB (2002) Long bone articular and diaphyseal structure in Old World monkeys and apes. I: locomotor effects. Am J Phys Anthropol 119:305-342.

Ruff CB, Hayes WC (1983) Cross-sectional geometry of the Pecos Pueblo femora and tibiae - a biomechanical investigation. I: methods and general pattern of variation. Am J Phys Anthropol 60:359-381.

Ruff C, Hayes W (1988) Sex differences in age-related remodeling of the femur and tibia. J. Orthop Res 6:886-896.

Ruff CB, Holt BM, Sládek V, Berner M, Murphy W, zur Nedden D, Seidler H, Recheis W (2006a) Body size, body proportions, and mobility in the Tyrolean 'Iceman’. J Hum Evol 51:91-101.

Ruff CB, Holt B, Trinkaus E (2006b) Who’s afraid of the big bad Wolff? 'Wolff’s law’ and bone functional adaptation. Am J Phys Anthropol 129:484-498.

Ruff CB, Scott WW, Liu AY-C (1991) Articular and diaphyseal remodeling of the proximal femur with changes in body mass in adults. Am J Phys Anthropol 86:397-413. 
Sabick M, Torry M, Kim Y, Hawkins R (2004) Humeral torque in professional baseball pitchers. Am J Sports Med 32:892-898.

Salazar-García DC, Aura JE, Olària CR, Talamo S, Morales JV, Richards MP (2014) Isotope evidence for the use of marine resources in the Eastern Iberian Mesolithic. J Archaeol Sci42:231-240.

Salazar-García DC, Fontanals-Coll M, Goude G, Subirà E (2018) “To ‘seafood’ or not to seafood?” An isotopic perspective on dietary preferences at the Mesolithic-Neolithic transition in the Western Mediterranean. Quat Int 470:497-510.

Samsel M (2018) Microévolution et bioarchéologie des groupes humains de la fin du Pléistocène et du début de l'Holocène en Europe occidentale : apports de l'anthropologie biologique aux connaissances sur le Paléolithique final et le Mésolithique. Dissertation, Université de Bordeaux. https://tel.archives-ouvertes.fr/tel-01897808/document

Schmitt A (2005) Une nouvelle méthode pour estimer l'âge au décès des adultes à partir de la surface sacro-pelvienne iliaque. Bull Mem Soc Anthropol Paris 17:89-101.

Schmitt A, Georges P (2008) Quelle démarche suivre pour estimer l'âge au décès à partir du squelette? In: Charlier P (ed) Ostéo-archéologie et techniques médico-légales: tendances et perspectives. Editions De Boccard, Paris, pp. 269-280.

Schmitt D, Churchill SE, Hylander WL (2003) Experimental evidence concerning spear use in Neanderthals and Early Modern humans. J Archaeol Sci 30:103-114.

Schulting RJ, Richards MP (2002) Finding the coastal Mesolithic in Southwest Britain: AMS dates and stable isotope results on human remains from Caldey Island, South Wales. Antiquity 76:1011-1025.

Shaw C, Stock J (2009a) Intensity, repetitiveness, and directionality of habitual adolescent mobility patterns influence the tibial diaphysis morphology of athletes. Am J Phys Anthropol 140:149-159.

Shaw C, Stock J (2009b) Habitual throwing and swimming correspond with upper limb diaphyseal strength and shape in modern human athletes. Am J Phys Anthropol 140:160-172.

Shaw CN, Stock JT (2013) Extreme mobility in Late Pleistocene? Comparing limb biomechanics among fossil Homo, varsity athletes and Holocene foragers. J Hum Evol 64:242-249. 
Shea JJ (2006) The origins of lithic projectile point technology: evidence from Africa, the Levant, and Europe. J Archaeol Sci 33:823-846.

Sládek V, Trinkaus E, Hillson SW, Holliday TW. 2000. The people of the Pavlovian. Skeletal catalogue and osteometrics of the Gravettian fossil hominids from Dolní Věstonice and Pavlov. Academy of Sciences of the Czech Republic, Brno.

Sládek V, Berner M, Sailer R (2006a) Mobility in Central European Late Eneolithic and Early Bronze Age: femoral cross-sectional geometry. Am J Phys Anthropol 130:320-332.

Sládek V, Berner M, Sailer R (2006b) Mobility in Central European Late Eneolithic and Early Bronze Age: tibial cross-sectional geometry. J Archaeol Sci 33:470-482.

Sládek V, Ruff CB, Berner M, Holt B, Niskanen V, Schuplerová E, Hora M (2016) The impact of subsistence changes on humeral bilateral asymmetry in Terminal Pleistocene and Holocene Europe J Hum Evol 92:37-49.

Smith RJ (2017) The continuing misuse of null hypothesis significance testing in biological anthropology. Am J Phys Anthropol 1-10. DOI: 10.1002/ajpa.23399.

Sparacello VS, Marchi D (2008) Mobility and subsistence economy: a diachronic comparison between two groups settled in the same geographical area (Liguria, Italy). Am J Phys Anthropol 136:485-495.

Sparacello VS, Marchi D, Shaw CS (2014) The importance of considering fibular robusticity when inferring the mobility patterns of past populations. In: Carlson K, Marchi D (eds) Reconstructing mobility: environmental, behavioral, and morphological determinants. Springer, New York, pp 91-111.

Sparacello VS, d’Ercole V, Coppa A (2015) A bioarchaeological approach to the reconstruction of changes in military organization among Iron Age Samnites (Vestini) from Abruzzo, central Italy. Am J Phys Anthropol 156:305-316.

Sparacello VS, Panelli C, Rossi S, Dori I, Varalli A, Goude G, Starnini E, Biagi P (2019a) The re-discovery of Arma dell'Aquila (Finale Ligure, Italy): New insights on Neolithic funerary behavior from the sixth millennium BCE in the north-western Mediterranean. Quat Int 512:67-81.doi.org/10.1016/j.quaint.2019.02.003. 
Sparacello VS, Pearson OM (2010) The importance of accounting for the area of the medullary cavity in cross-sectional geometry: a test based on the femoral midshaft. Am J Phys Anthropol 143:612-624.

Sparacello VS, Pearson OM, Coppa A, Marchi D (2011) Changes in robusticity in an Iron Age agropastoral group: the Samnites from the Alfedena necropolis (Abruzzo, Central Italy). Am J Phys Anthropol 144:119-130.

Sparacello VS, Varalli A, Rossi S, Panelli C, Goude G, Palstra SWL, Conventi M, Del Lucchese A, Arobba D, De Pascale A, Zavattaro M, Garibaldi P, Rossi G, Molinari I, Maggi R, Moggi-Cecchi J, Starnini E, Biagi P, Dori I. (2019b). Dating the funerary use of caves in Liguria (northwestern Italy) from the Neolithic to historic times: results from a large-scale AMS campaign on human skeletal series. Quat Int doi.org/10.1016/j.quaint.2019.11.034. Sparacello VS, Villotte S, Shackelford LL, Erik Trinkaus (2017) Patterns of Humeral Asymmetry among Late Pleistocene Humans. Comptes Rendus Palevol 16(5-6):680-689. Sparacello VS, Villotte S, Shaw CN, Fontana F, Mottes E, Starnini E, Dalmeri G, Marchi D (2018) Changing mobility patterns at the Pleistocene-Holocene transition: the biomechanics of the lower limb of Italian Gravettian and Mesolithic individuals. In: Cristiani E, Borgia V (eds) Paleolithic Italy: Advanced studies on early human adaptations in the Apennine Peninsula. Sidestone Press, Leiden, pp 357-396.

Standen VG, Arriaza BT, Santoro CM (1997) External auditory exostosis in prehistoric Chilean populations: A test of the cold water hypothesis. Am J Phys Anthropol 103:119-129 Stevens RE, Jacobi RM, Higham TFG (2010) Reassessing the diet of Upper Palaeolithic humans from Gough's Cave and Sun Hole, Cheddar Gorge, Somerset, UK. J Archaeol Sci 37:52-61.

Stiner MC, Munro ND (2011) On the evolution of diet and landscape during the Upper Paleolithic through Mesolithic at Franchthi Cave (Peloponnese, Greece). J Hum Evol 60:618636.

Stiner M, Munro ND, Surovell TA, Tchernov E, Bar-Yosef O (1999) Paleolithic population growth pulses evidenced by small animal exploitation. Science 283:190-194.

Stirland AJ (1993) Asymmetry and activity-related change in the male humerus. Int J Osteoarchaeol 2:105-113. 
Stock J (2002) A test of two methods of radiographically deriving long bone cross-sectional properties compared to direct sectioning of the diaphysis. Int J Osteoarch 12:335-342.

Stock JT (2006) Hunter-gatherer postcranial robusticity relative to patterns of mobility, climatic adaptation, and selection for tissue economy. Am J Phys Anthropol 131:194-204.

Stock JT, Pfeiffer S (2001) Linking structural variability in long bone diaphyses to habitual behaviors: foragers from the southern African Later Stone Age and the Andaman Islands. Am J Phys Anthropol 115:337-348.

Stock JT, Shaw CN (2007) Which measures of skeletal robusticity are robust? A comparison of external methods of quantifying diaphyseal strength to cross-sectional geometric properties. Am J Phys Anthropol 134:412-423.

Straus LG, Altuna G, Clark G, González Morales M, Laville H, Leroi-Gourhan M, Menéndez de la Hoz M, Ortea J (1981) Paleoecology at La Riera. Curr Anthropol 22:655-682.

Tagliacozzo A (1993) Archeozoologia della Grotta dell’Uzzo, Sicilia. Supplemento di Bullettino di paletnologia italiana 84 vol II. Istituto Poligrafico e Zecca dello Stato, Rome. Trinkaus E, Buzhilova AP, Mednikova MB, Dobrovolskaya MV (2014) The People of Sunghir. Oxford University Press, New York.

Trinkaus E, Churchill SE, Ruff CB (1994) Postcranial robusticity in Homo. II. humeral bilateral asymmetry and bone plasticity. Am J Phys Anthropol 93:1-34.

Trinkaus E, Ruff CB (2012) Femoral and tibial diaphyseal cross-sectional geometry in Pleistocene Homo. Paleoanthropology 2012:13-62. doi:10.4207/PA.2012.ART69

Varalli A, Villotte S, Dori I, Sparacello VS (In Press) New insights into activity-related functional adaptations and entheseal changes in Neolithic Liguria (northwestern Italy). Bull Mem Soc Anthropol Paris.

Velasco-Vazquez J, Betancor-Rodriguez A, Arnay-De-La Rosa M, Gonzalez-Reimers E (2000) Auricular exostoses in the prehistoric population of Gran Canaria. Am J Phys Anthropol 112:49-55.

Verneau R (1906) Les grottes de Grimaldi (Baoussé-Roussé), Anthropologie, II-1. Imprimerie de Monaco, Monaco. 
Vickerton P, Jarvis J, Gallagher J, Akhtar R, Sutherland H, Jeffery N (2014) Morphological and histological adaptation of muscle and bone to loading induced by repetitive activation of muscle. Proc R Soc Lond B Biol Sci 281:20140786. 10.1098/rspb.2014.0786.

Villotte S (2006) Connaissances médicales actuelles, cotation des enthésopathies: nouvelle méthode. Bull Mém Soc Anthropol Paris 18:65-85

Villotte S (2009) Enthésopathies et Activité s des Hommes préhistoriques. Recherche Méthodologique et Application aux Fossiles Européens du Paléolithique Supérieur et du Mésolithique. Archaeopress, Oxford.

Villotte S, Assis S, Alves Cardoso F, Henderson CY, Mariotti V, Milella M, Pany-Kucera D, Speith N,Wilczak CA, Jurmain R (2016) In search of consensus: terminology for entheseal changes (EC). Int J of Paleopat 13:49-55.

Villotte S, Castex D, Couallier V, Dutour O, Knüsel C J et Henry-Gambier D (2010) Enthesopathies as occupational stress markers: evidence from the upper limb. Am J Phys Anthropol 142(2):224-234.

Villotte S, Churchill SE, Dutour OJ, Henry-Gambier D (2010) Subsistence activities and the sexual division of labor in the European Upper Paleolithic and Mesolithic: evidence from upper limb enthesopathies. J Hum Evol 59:35-43.

Villotte S, Knüsel C J, (2013) Understanding Entheseal Changes: Definition and Life Course Changes. Int J Osteoarchaeol 23(2):135-146.

Villotte S, Knüsel C (2013) Asymétries des atteintes des enthèses et des mesures linéaires du membre supérieur : résultats préliminaires pour un large échantillon préhistorique. Bull Mem Soc Anthropol Paris 25(suppl):42.

Villotte S, Stefanović S, Knüsel CJ (2014) External auditory exostoses and aquatic activities during the Mesolithic and the Neolithic in Europe: Results from a large prehistoric sample. Anthropologie 52:73-89.

Villotte S, Knüsel CJ (2016) External auditory exostoses and prehistoric aquatic resource procurement. J Archaeol Sci Rep 6(4):633-6.

Villotte S, Samsel M, Sparacello VS (2017) The paleobiology of the two adult skeletons from Baousso da Torre (Bausu da Ture) (Liguria, Italy): implications for our understanding of Gravettian lifestyle. Comptes Rendus Palevol 16:462-473. 
Walker M, Johnsen S, Rasmussen SO, Popp T, Steffensen J-P, Gibbard P, Hoek W, Lowe J, Andrews J, Björk S, Cwynar LC, Hugen K, Kershaw P, Kromer B, Litt T, Lowe DJ, Nakagawa T, Newnham R, Schwander J (2009) Formal definition and dating of the GSSP (Global Stratotype Section and Point) for the base of the Holocene using the Greenland NGRIP ice core, and selected auxiliary records. J Quat Sci 24:3-17.

Weiss E (2003) Effects of rowing on humeral strength. Am J Phys Anthropol 121(4):293302.

Whittaker JC, Kamp KA (2006) Primitive weapons and modern sport: atlatl capabilities, learning, gender, and age. Plains Anthropol 198:213-221.

Wojtal P, Wilczyński J (2015a) World of Gravettian hunters. Quat Int 359-360:1-2.

Wojtal P, Wilczyński J (2015b) Hunters of the giants: woolly mammoth hunting during the Gravettian in Central Europe. Quat Int 379:71-81.

Zvelebil M (2001) The agricultural transition and the origins of Neolithic society in Europe. Documenta Praehistorica 28:1-26. https://doi.org/10.4312/dp.28.1

Zvelebil M (2008) Innovating hunter-gatherers: the Mesolithic of the Baltic. In: Bailey G, Spikins P (eds) Mesolithic Europe. Cambridge University Press, Cambridge, pp 18-59. 


\begin{tabular}{|l|c|c|c|}
\hline $\begin{array}{l}\text { Sicilian Mesolithic } \\
\text { sample }\end{array}$ & Age & $\begin{array}{c}\text { Sex } \\
\text { literature }\end{array}$ & $\begin{array}{c}\text { Sex } \\
\text { (Samsel, } \\
\text { 2018) }\end{array}$ \\
\hline Grotta d,Oriente B & $>50$ & & $\mathrm{~F}$ \\
\hline Grotta della Molara 1 & Adult & & $\mathrm{U}$ \\
\hline Grotta della Molara 2 & Adult & & $\mathrm{M}$ \\
\hline Grotta dell’Uzzo 1A & $20-39$ & $\mathrm{~F}$ & $\mathrm{~F}$ \\
\hline Grotta dell’Uzzo 1B & $20-29$ & $\mathrm{M}$ & $\mathrm{F}$ \\
\hline Grotta dell’Uzzo 2 & $>40$ & $\mathrm{M}$ & $\mathrm{M}$ \\
\hline Grotta dell’Uzzo 4A & Adult & $\mathrm{M}$ & $\mathrm{U}$ \\
\hline Grotta dell’Uzzo 4B & $20-49$ & $\mathrm{~F}$ & $\mathrm{~F}$ \\
\hline Grotta dell’Uzzo 5 & $>30$ & $\mathrm{M}$ & $\mathrm{M}$ \\
\hline Grotta dell’Uzzo 7 & Adult & $\mathrm{M}$ & $\mathrm{M}$ \\
\hline Grotta dell’Uzzo 8 & Adult & $\mathrm{F} / \mathrm{U}$ & $\mathrm{U}$ \\
\hline Grotta dell’Uzzo 10 & $20-29$ & $\mathrm{~F}$ & $\mathrm{U}$ \\
\hline Grotta dell’Uzzo 11 & $20-29$ & $\mathrm{M}$ & $\mathrm{M}$ \\
\hline
\end{tabular}

Table 1 - The sample of Sicilian Mesolithic individuals used in this study.

${ }^{1}$ From Borgognini Tarli 1976; Borgognini Tarli, 1980; Borgognini Tarli and Repetto, 1986; Borgognini Tarli et al., 1993; Di Salvo et al., 2012a,b. M: male; F: female; U: undetermined. 


\begin{tabular}{|c|c|c|c|}
\hline $\begin{array}{l}\text { Cultural } \\
\text { Period }\end{array}$ & $\mathbf{N}$ & Individuals & Data Source \\
\hline $\begin{array}{l}\text { Mid Upper } \\
\text { Paleolithic }\end{array}$ & $\begin{array}{l}\text { Total: } 36 \\
\text { Males: } 20 \\
\text { Females: } 9 \\
\text { Undetermined Sex: } 7\end{array}$ & $\begin{array}{l}\text { Abri Pataud 3, Barma Grande 21 , 5, 6; Bausso da Ture 1, 2; Barma del Caviglione 1; Cro } \\
\text { Magnon } 1 \text { (4296, 4327, 4332), 4294, 4295, 4322, 4324, 4330, 4333; Dolní Věstonice 3, } 13 \text {, } \\
\text { 14, 16, 35; Grotte des Enfants 4, 5; Neuessing 2; Ostuni 1; Paglicci 25; Parabita 1, 2; } \\
\text { Paviland 1; Pavlov 1; Předmostí 1, 3, 4, 5, 9, 10, 14; Sunghir 1, 4. }\end{array}$ & $\begin{array}{l}\text { Vernau, 1906; Matiegka, 1934, } \\
\text { 1938; Pearson, 1997; Holt, 1999; } \\
\text { Sládek et al., 2000; Trinkaus and } \\
\text { Ruff, 2012; Trinkaus et al., 2014; } \\
\text { Sparacello et al., 2017, 2018. }\end{array}$ \\
\hline $\begin{array}{l}\text { Late Upper } \\
\text { Paleolithic }\end{array}$ & $\begin{array}{l}\text { Total:32 } \\
\text { Males: } 19 \\
\text { Females: } 11 \\
\text { Undetermined Sex: } 2\end{array}$ & $\begin{array}{l}\text { Arene Candide 2, 3, 4, 5, 10, 12; Bichon; Cap Blanc; Chancelade; Continenza 7; Cova Fosca } \\
\text { A1 AD, Gough’s Cave; Grotte des Enfants 3; Lafaye; Laugerie Basse 4, Los Azules, Maritza } \\
\text { 2; Oberkassel 1, 2; Peyrat 5, Riparo Tagliente; Rochereil; Romanelli 1; Romito 1-6; San } \\
\text { Teodoro 1, 4; Saint-Germain-de-la-Rivière 4; Villabruna. }\end{array}$ & $\begin{array}{l}\text { Holt, 1999; Sparacello et al., 2014, } \\
\text { 2017, } 2018 .\end{array}$ \\
\hline Mesolithic & $\begin{array}{l}\text { Total: } 40 \\
\text { Males: } 26 \\
\text { Females: } 14\end{array}$ & $\begin{array}{l}\text { Birsmatten; Blocksbjerg 251; Bottendorf; Culoz 1, 2; Dragsholm A, B; Gramat 1; Hoëdic 1, } \\
\text { 2, 4, 5, 6, 8, 9, 10; Holmegaard; Koelbjerg; Korsor Glas; Le Rastel; Loschbour; Melby; } \\
\text { Moita de Sebastiao 1, 2, 3, 7, 9, 18, 31; Sejerø; Téviec 1, 3, 4, 7, 8, 9, 11, 16; Unseburg; } \\
\text { Vaegensø. }\end{array}$ & Holt, 1999. \\
\hline Neolithic & $\begin{array}{l}\text { Total: } 34 \\
\text { Males: } 16 \\
\text { Females: } 17 \\
\text { Undetermined Sex: } 1\end{array}$ & $\begin{array}{l}\text { Arma del Morto 251+254; Arene Candide } 6 \text { Pe, } 7 \text { Pe, } 8 \text { Pe, II BB, III BB, IV BB, VI BB, VII } \\
\text { BB, IX BB; Arma dell’Aquila } 1 \text { Zambelli; Bergeggi 2, 3, 4, 5; Pian del Ciliegio; Pipistrelli 3, } \\
\text { 5, 6; Pollera } 1 \text { Tiné, } 10 \text { Pe, 110a, 110b, } 12 \text { Pe, } 13 \text { Pe, } 14 \text { Pe, } 22 \text { Pe, } 30 \text { Pe, } 32 \text { Pe, } 33 \text { Pe, } 6246 \\
\text { Pe, 6673.6 FI, 6690bis.3+6692.1. }\end{array}$ & $\begin{array}{l}\text { Marchi et al., 2006, 2011; Marchi, } \\
\text { 2008; Sparacello and Marchi, } \\
\text { 2008; Sparacello et al., 2011, 2014, } \\
\text { 2018, 2019a, b. }\end{array}$ \\
\hline
\end{tabular}

Table 2 - The bioarchaeological samples employed in this study for CSG analysis, and the references used for published data. ${ }^{1}$ Humeral data not included - possibly pathological asymmetry (Churchill and Formicola, 1997).

${ }^{2}$ Data for Ligurian Neolithic individuals include only the ones attributed to the Square Mouthed Pottery chronology (c. 5,000-4,300 cal BCE) thanks to the recently performed AMS dates on human bone (e.g. Sparacello et al., 2019a, b). 


\begin{tabular}{|c|c|c|}
\hline $\begin{array}{l}\text { Cultural } \\
\text { Period }\end{array}$ & $\mathbf{N}$ & Individuals \\
\hline $\begin{array}{l}\text { Mid Upper } \\
\text { Paleolithic }\end{array}$ & $\begin{array}{l}\text { Total: } 20 \text {; } \\
\text { Males: } 10 \text {; } \\
\text { Females: } 7 \text {; } \\
\text { Undetermined Sex: } 3 \text {. }\end{array}$ & $\begin{array}{l}\text { Abri Pataud 1, 3, 5; Baousso da Torre 2; Barma Grande 5, 6; Cro-Magnon 2, 3; Dolni } \\
\text { Vestonice 3, 13, 15, 16; Grotte des Enfants 4, 5; Ostuni 1, Paglicci 25, Paviland, Sunghir 1, } \\
\text { Veneri Parabita 1, } 2 .\end{array}$ \\
\hline $\begin{array}{l}\text { Late Upper } \\
\text { Paleolithic }\end{array}$ & $\begin{array}{l}\text { Total:35; } \\
\text { Males: 16; } \\
\text { Females: 10; } \\
\text { Undetermined Sex: } 9 .\end{array}$ & $\begin{array}{l}\text { Arene Candide 4, 10, 12, 14; Bichon, Chancelade, Continenza 7, Grotte des Enfants 3, } \\
\text { Lafaye 1, Laugerie Basse 4, Maritza 2, Romanelli 1, Romito 3, 4, 5, 6, 7; Saint Germain La } \\
\text { Rivière 4, San Teodoro 1, 3, 4, 5; Stare Mesto 1, Tagliente 2, Vado All’ Arancio 1, } \\
\text { Vasilievka III 10, 12, 13, 22, 28, 35, 36, 37, 38; Villabruna } 1\end{array}$ \\
\hline Mesolithic & $\begin{array}{l}\text { Total: 200; } \\
\text { Males: 73; } \\
\text { Females: 81; } \\
\text { Undetermined Sex: } 46 .\end{array}$ & $\begin{array}{l}\text { Individuals from Muge and Sado sites : (Amoreira: } 6 \text { ind.; Arapouco: 16; Arruda:45, Pez: 9; } \\
\text { Poças de S. Bento: 2; Romeiras: 2; Sebastiao: 54); from Brittany (Hoëdic: 7; Teviec: 8), from } \\
\text { the Iron Gates (Kula:3; Padina: 7; Schela Cladovei: 18); Auneau 3; Birsmatten Basisgrotte, } \\
\text { Fatma Koba, Gough cave 1, La Brana 1, 2; La Chaussée-Tirancourt, Lavergne ST03, ST10 } \\
\text { (inf), ST11(1); Le Closeaux 1, Loschbour, Murzak Koba 1, } 2 \text {; Vasilievka II 08, 11, 12, 14, } \\
\text { 18, 21, 24, 25, } 27\end{array}$ \\
\hline Neolithic & $\begin{array}{l}\text { Total: } 257 ; \\
\text { Males: } 116 ; \\
\text { Females: } 114 \text {; } \\
\text { Undetermined Sex: } 27 .\end{array}$ & $\begin{array}{l}\text { Ajmana (4 ind.), Barmaz I (20), Barmaz II (14), Chamblandes (26), Corseaux (9), Gurgy } \\
\text { (32), Pontcharauld (40), Sion Collines (10), Sion Ritz (9), Saint Guerin (3), Saint Leonard } \\
\text { (2), Stuttgart-Mülhausen (88) }\end{array}$ \\
\hline
\end{tabular}

Table 3 - Comparative samples used for the ECs analysis. All data recorded by SV. 


\begin{tabular}{|c|c|c|c|c|c|c|c|c|c|c|c|c|c|}
\hline & Molara 1 & Molara 2 & OrienteB & Uzzo 1A & Uzzo 1B & Uzzo 2 & Uzzo 4A & Uzzo 4B & Uzzo 5 & Uzzo 7 & Uzzo 8 & Uzzo 10 & Uzzo 11 \\
\hline Sex & $\mathbf{U}$ & $\mathbf{M}$ & $\mathbf{F}$ & $\mathbf{F}$ & $\mathbf{F}$ & $\mathbf{M}$ & $\mathbf{U}$ & $\mathbf{F}$ & $\mathbf{M}$ & $\mathbf{M}$ & $\mathbf{U}$ & $\mathbf{U}$ & $\mathbf{M}$ \\
\hline AGE & Adult & Adult & $>50$ & 20-39 & $20-29$ & $>40$ & Adult & $20-49$ & $>30$ & Adult & Adult & $20-29$ & $20-29$ \\
\hline \multicolumn{14}{|l|}{ Humerus right } \\
\hline Maximum length & & 330.8 & 293.5 & 288.5 & 307.0 & & 293.5 & 300.0 & 306.0 & 312.0 & & & \\
\hline Physiological length & & 326.0 & 290.5 & 285.5 & 304.0 & & 292.5 & 296.0 & 304.0 & 309.0 & $293^{1}$ & $264^{2}$ & $305^{1}$ \\
\hline J mid-distal & 16147.04 & 20757.91 & 14047.03 & 11018.86 & 12441.62 & & 11809.51 & 10676.12 & 15355.86 & 13712.19 & 8380.56 & 3525.19 & 15492.24 \\
\hline J midshaft & & 27943.08 & 18017.89 & 13613.55 & 14694.29 & & 13768.39 & 14038.71 & 16573.52 & 16723.43 & & 5423.59 & 22053.76 \\
\hline \multicolumn{14}{|l|}{ Humerus left } \\
\hline Maximum length & & 331.2 & 287.5 & 288.2 & 304.2 & & 292.0 & 294.0 & 305.0 & & & 257.0 & \\
\hline Physiological length & & 327.0 & 284.5 & 285.0 & 301.0 & & 291.0 & 289.0 & 302.0 & $307^{2}$ & $290^{2}$ & 257.0 & $303^{1}$ \\
\hline J mid-distal & 15689.13 & 21995.92 & 13935.43 & 9306.26 & 11022.30 & & 12804.00 & 10331.95 & 13627.73 & 13599.56 & & 3617.98 & 16810.60 \\
\hline J midshaft & & 24604.62 & 18310.16 & 11129.85 & 13157.33 & & 15245.12 & 13098.92 & 15102.18 & 16739.89 & & 4925.22 & 21873.10 \\
\hline \multicolumn{14}{|l|}{ Femur } \\
\hline Maximum length & & 465.2 & $407^{3}$ & 382.9 & 417 & 405.1 & & & 428 & 425.6 & & & 434.1 \\
\hline Mechanical length ${ }^{4}$ & & 439 & $383^{5}$ & 358 & 393.5 & 381 & & & 401.5 & 402 & & & $409^{5}$ \\
\hline FEMHSI & & 49.5 & 43 & 41.5 & 43 & 44.4 & & & 45 & 45.6 & & & 43 \\
\hline J midshaft & & 97086.83 & 62015.91 & 37757.71 & 43444.85 & 56725.48 & 49872.49 & 55942.94 & 46320.42 & 53830.99 & 41060.66 & 13871.84 & 75624.95 \\
\hline $\mathrm{Ix} / \mathrm{Iy}$ & & 1.38 & 1.13 & 1.41 & 1.23 & 1.34 & 1.18 & 1.34 & 1.25 & 1.61 & 1.43 & 1.27 & 1.70 \\
\hline \multicolumn{14}{|l|}{ Tibia } \\
\hline Maximum length & & 393 & 342 & 338 & 359 & 359 & & & 368 & 370 & & & 351 \\
\hline Mechanical length & & 380 & 329 & 322 & 345 & 345 & & & 354 & 359 & & & 338 \\
\hline J midshaft & & 87529.14 & 35926.83 & 27275.50 & 36949.90 & 40844.16 & & & 49147.44 & 50523.02 & 27732.29 & 10960.29 & 51727.59 \\
\hline Imax/Imin & & 2.10 & 2.10 & 2.55 & 2.43 & 2.26 & & & 2.26 & 2.15 & 2.13 & 2.21 & 1.79 \\
\hline Bodymass $^{7}$ & & 74.23 & 59.90 & 56.55 & 59.90 & 61.28 & & & 62.67 & 64.07 & & & 58.02 \\
\hline
\end{tabular}

Table 4 - Cross-sectional geometric properties discussed in this study and the relevant osteometric measurements for the Sicilian Mesolithic sample. Legend: M, males; F, females; U: sex is uncertain. FEMHSI: femoral head supero-inferior diameter.

${ }^{1}$ Estimated from ulnar mechanical length (Ruff, 2002) using the regression equation based on the rest of the Sicilian Mesolithic sample (n=6): Humerus M2 = -5.2383 + 1.3613* UL_MECH; $r^{2}=0.8781$. 
${ }^{2}$ Estimated from the opposite side using the regression equation based on the rest of the Sicilian Mesolithic sample ( $\mathrm{n}=7$ ): Humerus M2L= $-31.9675+1.0976 *$ Humerus $\mathrm{M} 2 \mathrm{R} ; \mathrm{r}^{2}=0.9704$

${ }^{3}$ Estimated based on the distance from the adductor tubercle (medial condyle) to the top of the femoral head. Regression based on the rest of the sicilian MESO sample ( $\mathrm{n}=7$ ) Femur M1=12.7277 + 1.0669*FEMADT r2=0.988.

${ }^{4}$ Mechanical length as defined in Ruff, 2002.

${ }^{5}$ Estimated based on maximum femoral length using the regression equation based on the rest of the Sicilian MESO sample ( $\mathrm{n}=6$ ): FEMMECH=-15.7231+0.9784*Femur M1 $\mathrm{r}^{2}=0.998$.

${ }^{6}$ Body mass was estimated from the superoinferior diameter of the femoral head following the guidelines in Trinkaus and Ruff (2012), where three sets of formulae for body mass estimation (all from recent humans) were used for individuals of contrasting body sizes. The formula from McHenry (1994) was used for individuals with femoral head superoinferior diameters of $<38 \mathrm{~mm}$. An average of the estimates from McHenry (1992), Ruff et al. (1991), and Grine et al. (1995) was used for individuals whose femoral head diameter was between 38 and $47 \mathrm{~mm}$. An average of Ruff et al. (1991) and Grine et al. (1995) was used for individuals whose femoral head diameter exceeded 47 mm. 


\begin{tabular}{|c|c|c|c|c|c|c|c|c|c|c|c|c|c|c|c|c|}
\hline \multirow{3}{*}{$\begin{array}{l}\text { Humerus CSG } \\
\text { Males } \\
\text { Zp mid-distal R }\end{array}$} & \multicolumn{3}{|c|}{ MUP } & \multicolumn{3}{|c|}{ LUP } & \multicolumn{3}{|c|}{ MESOSIC } & \multicolumn{3}{|c|}{ NEOL } & \multirow{2}{*}{$\begin{array}{c}\begin{array}{c}\text { Main Effect } \\
\text { (period) }\end{array} \\
\text { ANOVA }\end{array}$} & \multicolumn{2}{|c|}{\begin{tabular}{c|c} 
MUP- & LUP- \\
MESOSIC & MESOSIC \\
\end{tabular}} & \multirow{2}{*}{$\begin{array}{l}\text { NEOL- } \\
\text { MESOSIC } \\
\text { le } \\
\text { rroni) }\end{array}$} \\
\hline & $\mathbf{n}$ & Mean & SD & $\mathbf{n}$ & Mean & SD & $\mathbf{n}$ & Mean & SD & $\mathbf{n}$ & Mean & SD & & \multicolumn{2}{|c|}{$\begin{array}{c}\text { Post-hoc multiple } \\
\text { comparisons (Bonferroni) }\end{array}$} & \\
\hline & 10 & 54.32 & 9.58 & 13 & 52.03 & 7.13 & 4 & 58.96 & 4.83 & 14 & 54.19 & 9.97 & NS & NS & NS & NS \\
\hline Zp midshaft $R$ & 10 & 51.23 & 8.12 & 15 & 60.65 & 8.53 & 4 & 10.18 & 10.33 & 14 & 61.08 & 10.03 & $\mathrm{P}<0.01$ & $\mathrm{P}<0.01$ & NS & NS \\
\hline Zp mid-distal L & 11 & 37.55 & 6.68 & 13 & 42.28 & 10.53 & 4 & 59.51 & 7.26 & 15 & 48.68 & 7.78 & $\mathrm{P}<0.001$ & $\mathrm{P}<0.001$ & $\mathrm{P}<0.01$ & NS \\
\hline Zp midshaft $L$ & 13 & 40.64 & 6.67 & 14 & 50.58 & 12.71 & 4 & 67.71 & 11.08 & 15 & 53.88 & 8.31 & $\mathrm{P}<0.001$ & $\mathrm{P}<0.001$ & $\mathrm{P}<0.05$ & $\mathrm{P}<0.1$ \\
\hline & & & & & & & & & & & & & $\begin{array}{c}\text { Kruskal-Wallis } \\
\text { ANOVA }\end{array}$ & \multicolumn{3}{|c|}{$\begin{array}{c}\text { Multiple comparisons } \\
\text { of mean ranks }\end{array}$} \\
\hline HUMBA 35\% & 9 & 62.42 & 23.49 & 14 & 58.61 & 28.03 & 4 & 6.99 & 4.96 & 14 & 19.35 & 9.32 & $\mathrm{P}<0.001$ & $\mathrm{P}<0.01$ & $\mathrm{P}<0.01$ & NS \\
\hline HUMBA 50\% & 10 & 44.43 & 27.45 & 14 & 58.28 & 29.47 & 4 & 6.06 & 6.65 & 14 & 23.73 & 15.65 & $\mathrm{P}<0.001$ & $\mathrm{P}=0.05$ & $\mathrm{P}<0.01$ & NS \\
\hline Females & $\mathbf{n}$ & Mean & SD & $\mathbf{n}$ & Mean & SD & $\mathbf{n}$ & Mean & SD & $\mathbf{n}$ & Mean & SD & ANOVA & \multicolumn{3}{|c|}{$\begin{array}{c}\text { Post-hoc multiple } \\
\text { comparisons (Bonferroni) }\end{array}$} \\
\hline Zp mid-distal $\mathbf{R}$ & 2 & 42.6 & 11.64 & 4 & 49.24 & 8.06 & 3 & 56.58 & 4.03 & 12 & 45.72 & 4.47 & $\mathrm{P}<0.05$ & NS & NS & NS \\
\hline Zp midshaft $R$ & 6 & 47.57 & 8.72 & 5 & 57.07 & 8.66 & 3 & 66.16 & 6.64 & 12 & 58.93 & 14.42 & NS & NS & NS & NS \\
\hline Zp mid-distal L & 3 & 37.56 & 5.59 & 5 & 48.15 & 7.51 & 3 & 53.56 & 7.48 & 14 & 46.38 & 4.82 & $\mathrm{P}<0.05$ & $\mathrm{P}<0.05$ & NS & NS \\
\hline Zp midshaft L & 7 & 42.58 & 5.78 & 4 & 52.96 & 4.22 & 3 & 62.69 & 11.45 & 13 & 55.13 & 10.99 & $\mathrm{P}<0.05$ & $\mathrm{P}<0.05$ & NS & NS \\
\hline & & & & & & & & & & & & & $\begin{array}{c}\text { Kruskal-Wallis } \\
\text { ANOVA }\end{array}$ & \multicolumn{3}{|c|}{$\begin{array}{c}\text { Multiple comparisons } \\
\text { of mean ranks }\end{array}$} \\
\hline HUMBA 35\% & 3 & 12.94 & 12.66 & 4 & 12.52 & 2.81 & 4 & 8.85 & 8.22 & 13 & 6.94 & 5.76 & NS & NS & NS & NS \\
\hline HUMBA 50\% & 7 & 16.15 & 14.6 & 7 & 18.17 & 15.62 & 4 & 10.7 & 8.77 & 13 & 11.99 & 8.47 & NS & NS & NS & NS \\
\hline $\begin{array}{l}\text { Sexual } \\
\text { dimorphism }\end{array}$ & \multicolumn{3}{|c|}{ MUP } & \multicolumn{3}{|c|}{ LUP } & \multicolumn{3}{|c|}{ MESOSIC } & \multicolumn{3}{|c|}{ NEOL } & & & & \\
\hline Zp mid-distal $R$ & \multicolumn{3}{|c|}{ NS } & \multicolumn{3}{|c|}{ NS } & \multicolumn{3}{|c|}{ NS } & \multicolumn{3}{|c|}{$\mathrm{P}<0.05$} & & & & \\
\hline Zp midshaft $R$ & \multicolumn{3}{|c|}{ NS } & \multicolumn{3}{|c|}{ NS } & \multicolumn{3}{|c|}{ NS } & \multicolumn{3}{|c|}{ NS } & & & & \\
\hline Zp mid-distal L & \multicolumn{3}{|c|}{ NS } & \multicolumn{3}{|c|}{ NS } & \multicolumn{3}{|c|}{ NS } & \multicolumn{3}{|c|}{ NS } & & & & \\
\hline Zp midshaft $L$ & \multicolumn{3}{|c|}{ NS } & & NS & & & NS & & & NS & & & & & \\
\hline HUMBA $35 \%{ }^{1}$ & & $\mathrm{P}<0.0$ & & & $\mathrm{P}<0.0$ & & & NS & & & $\mathrm{P}<0.00$ & & & & & \\
\hline HUMBA $50 \%{ }^{1}$ & & $\mathrm{P}<0.0$ & & & $\mathrm{P}<0.0$ & & & NS & & & $\mathrm{P}<0.1$ & & & & & \\
\hline
\end{tabular}

Table 5 - Humeral CSG data. Legend: MUP, Middle Upper Paleolithic; LUP, Late Upper Paleolithic; MESOSIC, Sicilian Mesolithic; NEOL, Neolithic. ${ }^{1}$ Mann-Whitney U Test. 


\begin{tabular}{|c|c|c|c|c|c|c|c|c|c|c|c|c|c|c|c|c|c|c|c|c|}
\hline \multirow{3}{*}{$\begin{array}{l}\text { Lower Limb } \\
\text { CSG } \\
\text { Males } \\
\text { Femur Zp }\end{array}$} & \multicolumn{3}{|c|}{ MUP } & \multicolumn{3}{|c|}{ LUP } & \multicolumn{3}{|c|}{ MESOEURO } & \multicolumn{3}{|c|}{ MESOSIC } & \multicolumn{3}{|c|}{ NEOL } & \multirow{2}{*}{$\begin{array}{c}\begin{array}{c}\text { Main Effect } \\
\text { (period) }\end{array} \\
\text { ANOVA }\end{array}$} & \multirow[t]{2}{*}{$\begin{array}{c}\text { MUP } \\
\text { MESOSI } \\
\mathrm{C}\end{array}$} & \multirow{2}{*}{\multicolumn{2}{|c|}{\begin{tabular}{c|c} 
LUP & MESOEUR \\
MESOSI & O \\
C & MESOSIC \\
\multicolumn{2}{|c|}{ Post-hoc multiple } \\
comparisons (Bonferroni)
\end{tabular}}} & \multirow[t]{2}{*}{$\begin{array}{c}\text { NEOL } \\
\text { MESOSI } \\
\quad \mathrm{C} \\
\end{array}$} \\
\hline & $\mathbf{n}$ & Mean & SD & $\mathbf{n}$ & $\begin{array}{c}\text { Mea } \\
\text { n }\end{array}$ & SD & $\mathbf{n}$ & $\begin{array}{c}\text { Mea } \\
\text { n }\end{array}$ & SD & $\mathbf{n}$ & $\begin{array}{c}\text { Mea } \\
\text { n }\end{array}$ & SD & $\mathbf{n}$ & Mean & SD & & & & & \\
\hline & 19 & 103.7 & $\begin{array}{c}22.9 \\
5\end{array}$ & $\begin{array}{l}1 \\
8\end{array}$ & $\begin{array}{c}106 . \\
2\end{array}$ & $\begin{array}{c}10.5 \\
3\end{array}$ & $\begin{array}{l}2 \\
0\end{array}$ & $\begin{array}{c}100.1 \\
4\end{array}$ & $\begin{array}{c}15.1 \\
4\end{array}$ & 5 & $\begin{array}{c}125.1 \\
4\end{array}$ & $\begin{array}{c}20.4 \\
8\end{array}$ & $\begin{array}{l}1 \\
4\end{array}$ & 102.14 & 13.99 & $\mathrm{P}<0.1$ & NS & NS & $\mathrm{P}<0.05$ & NS \\
\hline \multirow[t]{2}{*}{ Tibia Zp } & 18 & 108.5 & 28.3 & $\begin{array}{l}1 \\
6\end{array}$ & $\begin{array}{c}109 . \\
4\end{array}$ & $\begin{array}{c}15.7 \\
8\end{array}$ & $\begin{array}{l}1 \\
7\end{array}$ & $\begin{array}{c}103.8 \\
8\end{array}$ & $\begin{array}{c}20.5 \\
2\end{array}$ & 5 & $\begin{array}{c}126.4 \\
4\end{array}$ & $\begin{array}{c}14.9 \\
2\end{array}$ & $\begin{array}{l}1 \\
4\end{array}$ & 104.69 & 18.44 & NS & NS & NS & NS & NS \\
\hline & & & & & & & & & & & & & & & & $\begin{array}{c}\text { Kruskal- } \\
\text { Wallis } \\
\text { ANOVA }\end{array}$ & \multicolumn{4}{|c|}{$\begin{array}{l}\text { Multiple comparisons } \\
\text { of mean ranks }\end{array}$} \\
\hline Femur Ix/Iy & 19 & 1.48 & 0.33 & $\begin{array}{l}1 \\
8\end{array}$ & 1.4 & 0.25 & $\begin{array}{l}2 \\
6\end{array}$ & 1.15 & 0.16 & 5 & 1.38 & 0.24 & $\begin{array}{l}1 \\
4\end{array}$ & 1.32 & 0.17 & $\mathrm{P}<0.01$ & NS & NS & NS & NS \\
\hline $\begin{array}{l}\text { Tibia } \\
\text { Imax/Imin }\end{array}$ & 18 & 2.82 & 0.63 & $\begin{array}{l}1 \\
6\end{array}$ & 2.85 & 0.64 & $\begin{array}{l}2 \\
1\end{array}$ & 2.66 & 0.51 & 5 & 2.11 & 0.19 & $\begin{array}{l}1 \\
4\end{array}$ & 2.67 & 0.33 & $\mathrm{P}<0.05$ & $\mathrm{P}<0.1$ & $\mathrm{P}<0.05$ & NS & NS \\
\hline Females & $\mathbf{n}$ & Mean & SD & $\mathbf{n}$ & $\begin{array}{c}\text { Mea } \\
\text { n }\end{array}$ & SD & $\mathbf{n}$ & $\begin{array}{c}\text { Mea } \\
\text { n }\end{array}$ & SD & $\mathbf{n}$ & $\underset{\mathbf{n}}{\text { Mea }}$ & SD & $\mathbf{n}$ & Mean & SD & ANOVA & \multicolumn{4}{|c|}{$\begin{array}{c}\text { Post-hoc multiple } \\
\text { comparisons (Bonferroni) }\end{array}$} \\
\hline Femur Zp & 8 & 99.97 & $\begin{array}{c}17.7 \\
3\end{array}$ & 7 & $\begin{array}{c}96.7 \\
5\end{array}$ & $\begin{array}{c}13.3 \\
9\end{array}$ & $\begin{array}{l}1 \\
0\end{array}$ & 94.75 & $\begin{array}{c}11.8 \\
6\end{array}$ & 3 & $\begin{array}{c}116.2 \\
9\end{array}$ & $\begin{array}{c}18.4 \\
6\end{array}$ & $\begin{array}{l}1 \\
2\end{array}$ & 94.87 & 11.41 & NS & NS & NS & NS & NS \\
\hline \multirow[t]{2}{*}{ Tibia Zp } & 8 & 100.1 & $\begin{array}{c}30.5 \\
5\end{array}$ & 5 & $\begin{array}{c}101 . \\
2\end{array}$ & 8.44 & 8 & 92.6 & $\begin{array}{c}19.3 \\
9\end{array}$ & 3 & $\begin{array}{c}102.2 \\
9\end{array}$ & 6.46 & $\begin{array}{l}1 \\
3\end{array}$ & 97.15 & 15.53 & NS & NS & NS & NS & NS \\
\hline & & & & & & & & & & & & & & & & $\begin{array}{c}\text { Kruskal- } \\
\text { Wallis } \\
\text { ANOVA }\end{array}$ & \multicolumn{4}{|c|}{$\begin{array}{l}\text { Multiple comparisons } \\
\text { of mean ranks }\end{array}$} \\
\hline Femur Ix/Iy & 8 & 1.38 & 0.45 & $\begin{array}{l}1 \\
1\end{array}$ & 1.26 & 0.27 & $\begin{array}{l}1 \\
4\end{array}$ & 1.1 & 0.19 & 4 & 1.23 & 0.14 & $\begin{array}{l}1 \\
2\end{array}$ & 1.15 & 0.17 & NS & NS & NS & NS & NS \\
\hline $\begin{array}{l}\text { Tibia } \\
\text { Imax/Imin }\end{array}$ & 8 & 2.33 & 0.4 & 6 & 2.14 & 0.27 & $\begin{array}{l}1 \\
0\end{array}$ & 2.47 & 0.33 & 3 & 2.36 & 0.23 & $\begin{array}{l}1 \\
3\end{array}$ & 2.34 & 0.32 & NS & NS & NS & NS & NS \\
\hline $\begin{array}{l}\text { Sexual } \\
\text { dimorphism }\end{array}$ & \multicolumn{3}{|c|}{ MUP } & \multicolumn{3}{|c|}{ LUP } & \multicolumn{3}{|c|}{ MESOEURO } & \multicolumn{3}{|c|}{ MESOSIC } & \multicolumn{3}{|c|}{ NEOL } & & & & & \\
\hline Femur $Z_{p}$ & \multicolumn{3}{|c|}{ NS } & \multicolumn{3}{|c|}{ NS } & \multicolumn{3}{|c|}{ NS } & \multicolumn{3}{|c|}{ NS } & \multicolumn{3}{|c|}{ NS } & & & & & \\
\hline Tibia Zp & \multicolumn{3}{|c|}{ NS } & \multicolumn{3}{|c|}{ NS } & \multicolumn{3}{|c|}{ NS } & \multicolumn{3}{|c|}{$\mathrm{P}<0.05$} & \multicolumn{3}{|c|}{ NS } & & & & & \\
\hline Femur Ix/Iy ${ }^{1}$ & & NS & & & NS & & & NS & & & NS & & & $\mathrm{P}<0.0$ & & & & & & \\
\hline $\begin{array}{l}\text { Tibia } \\
\text { Imax/Imin } 1\end{array}$ & & $\mathrm{P}<0.1$ & & & $\mathrm{P}<0.01$ & & & NS & & & NS & & & $\mathrm{P}<0.0$ & & & & & & \\
\hline
\end{tabular}

Table 6 - Femoral and tibial CSG data. Legend: MUP, Middle Upper Paleolithic; LUP, Late Upper Paleolithic; MESOSIC, Sicilian Mesolithic; NEOL, Neolithic. ${ }^{1}$ MannWhitney U Test. 


\begin{tabular}{|c|c|c|c|c|c|c|c|c|c|c|c|c|}
\hline Uividual & Sex & Age & Side & $\begin{array}{c}\text { m. } \\
\text { subscapularis }\end{array}$ & $\begin{array}{c}\text { mm. infra } \\
\text { and } \\
\text { supraspinatus }\end{array}$ & $\begin{array}{l}\text { Common } \\
\text { extensors }\end{array}$ & $\begin{array}{l}\text { common } \\
\text { flexors }\end{array}$ & $\begin{array}{c}\text { mm. } \\
\text { semimembranosus } \\
\text { and biceps } \\
\text { femoris }\end{array}$ & $\begin{array}{c}\text { m. } \\
\text { gluteus } \\
\text { minimus }\end{array}$ & $\begin{array}{l}\text { m. } \\
\text { gluteus } \\
\text { medius }\end{array}$ & $\begin{array}{l}\text { m. } \\
\text { iliopsoas }\end{array}$ & EAE \\
\hline \multirow{2}{*}{ Molara 1} & \multirow{2}{*}{$\mathrm{U}$} & \multirow{2}{*}{ Adult } & $\mathrm{R}$ & & & & & & & & & \\
\hline & & & $\mathrm{L}$ & & & & & & & & & \\
\hline \multirow{2}{*}{ Molara 2} & \multirow{2}{*}{$\mathrm{M}$} & \multirow{2}{*}{ Adult } & $\mathrm{R}$ & & A & A & & & & & & \\
\hline & & & $\mathrm{L}$ & A & B & A & A & & & & & \\
\hline \multirow{2}{*}{ OrienteB } & \multirow{2}{*}{ F } & \multirow{2}{*}{$>50$} & $\mathrm{R}$ & A & A & A & A & A & A & A & & 0 \\
\hline & & & $\mathrm{L}$ & A & A & A & A & A & A & & & 0 \\
\hline \multirow{2}{*}{ Uzzo 1A } & \multirow{2}{*}{ F } & \multirow{2}{*}{$\begin{array}{c}20- \\
39\end{array}$} & $\mathrm{R}$ & A & B & A & & A & A & B & A & 0 \\
\hline & & & $\mathrm{L}$ & A & & A & & A & A & $\mathrm{B}$ & & 0 \\
\hline \multirow{2}{*}{ Uzzo 1B } & \multirow{2}{*}{ F } & \multirow{2}{*}{$\begin{array}{l}20- \\
29\end{array}$} & $\mathrm{R}$ & A & A & A & A & A & A & & & 0 \\
\hline & & & $\mathrm{L}$ & A & A & A & A & A & A & A & A & 0 \\
\hline \multirow{2}{*}{ Uzzo 2} & \multirow{2}{*}{$\mathrm{M}$} & \multirow{2}{*}{$>40$} & $\mathrm{R}$ & & & & & B & A & A & A & \\
\hline & & & $\mathrm{L}$ & & & & & & & & & \\
\hline \multirow{2}{*}{ Uzzo 4A } & \multirow{2}{*}{$\mathrm{U}$} & \multirow{2}{*}{ Adult } & $\mathrm{R}$ & B & B & A & A & & & & & 0 \\
\hline & & & $\mathrm{L}$ & A & A & A & A & & & & & 0 \\
\hline \multirow{2}{*}{ Uzzo 4B } & \multirow{2}{*}{ F } & \multirow{2}{*}{$\begin{array}{c}20- \\
49\end{array}$} & $\mathrm{R}$ & A & A & A & A & & & & & 0 \\
\hline & & & $\mathrm{L}$ & A & A & A & & & & & & 0 \\
\hline \multirow{2}{*}{ Uzzo 5} & \multirow{2}{*}{$\mathrm{M}$} & \multirow{2}{*}{$>30$} & $\mathrm{R}$ & A & & A & A & A & A & & & 1 \\
\hline & & & $\mathrm{L}$ & A & & A & A & A & A & A & A & 1 \\
\hline \multirow{2}{*}{ Uzzo 7} & \multirow{2}{*}{$\mathrm{M}$} & \multirow{2}{*}{ Adult } & $\mathrm{R}$ & & & A & B & & & & A & \\
\hline & & & $\mathrm{L}$ & & & A & A & A & A & A & A & \\
\hline \multirow{2}{*}{ Uzzo 8} & $\mathrm{U}$ & Adult & $\mathrm{R}$ & & & & A & B & & & & \\
\hline & & & $\mathrm{L}$ & & & & A & A & & A & & \\
\hline
\end{tabular}




\begin{tabular}{|c|c|c|c|c|c|c|c|c|c|c|c|c|}
\hline \multirow{2}{*}{ Uzzo 10} & \multirow{2}{*}{$\mathbf{U}$} & \multirow{2}{*}{$\begin{array}{c}20- \\
29\end{array}$} & $\mathbf{R}$ & & & A & & & & A & A & \\
\hline & & & $\mathrm{L}$ & A & A & A & A & A & A & A & A & 0 \\
\hline \multirow{2}{*}{ Uzzo 11} & \multirow{2}{*}{$\mathrm{M}$} & \multirow{2}{*}{$\begin{array}{c}20- \\
29\end{array}$} & $\mathrm{R}$ & A & & A & A & A & & & A & \\
\hline & & & $\mathrm{L}$ & & & A & A & & A & A & A & \\
\hline
\end{tabular}

Table 7 - ECs and EAEs scores for the Sicilian Mesolithic sample. A: no ECs, B: minor change. 0: no EAE, 1: minor EAE. R: Right, L: left.

\begin{tabular}{|l|c|c|c|c|c|c|}
\hline & \multicolumn{3}{|c|}{ Right upper limb } & \multicolumn{3}{c|}{ Left upper limb } \\
\hline & $\begin{array}{c}\text { N observed } \\
\text { entheses }\end{array}$ & N ECs & $\begin{array}{c}\text { \% of } \\
\text { ECs }\end{array}$ & $\begin{array}{c}\text { N observed } \\
\text { entheses }\end{array}$ & N ECs & $\begin{array}{c}\text { \% of } \\
\text { ECs }\end{array}$ \\
\hline MUP & 35 & 7 & $20.0 \%$ & 43 & 4 & $9.3 \%$ \\
\hline LUP & 68 & 12 & $17.6 \%$ & 60 & 4 & $6.7 \%$ \\
\hline MESO & 330 & 89 & $27.0 \%$ & 241 & 43 & $17.8 \%$ \\
\hline MESOSIC & 32 & 5 & $15.6 \%$ & 33 & 1 & $3.0 \%$ \\
\hline NEO & 576 & 187 & $32.5 \%$ & 497 & 85 & $17.1 \%$ \\
\hline
\end{tabular}

Table 8 - Frequencies of ECs for the right and left upper limb for the Sicilian Mesolithic sample and the comparative samples. As there is no control for age, the percentages cannot be compared between samples, but instead illustrate the variation of the differences between left and right sides through time. 


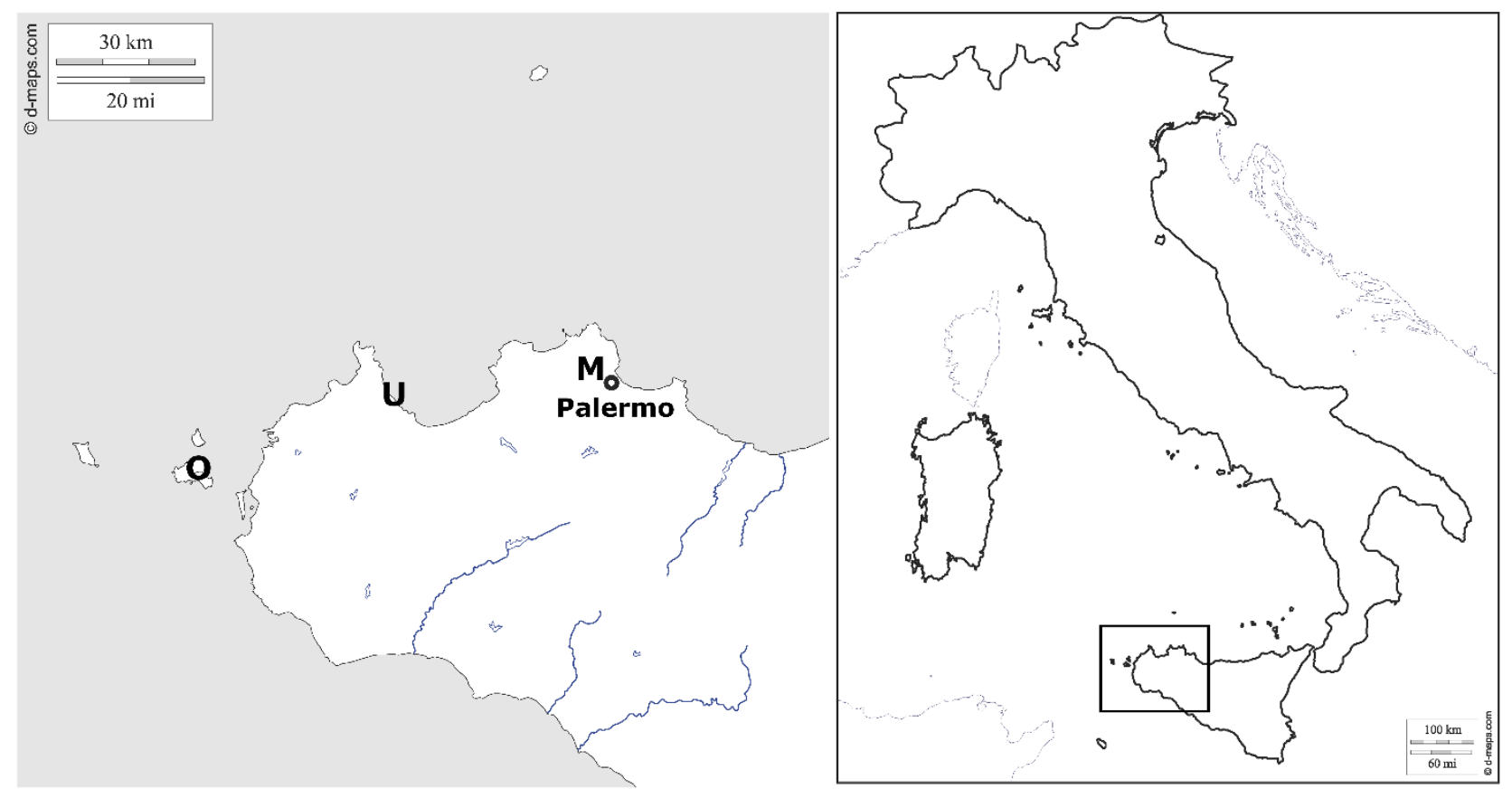

Figure 1 - Geographical collocation of the Sicilian sites included in this analysis. Maps were downloaded and modified from d-maps.com. 

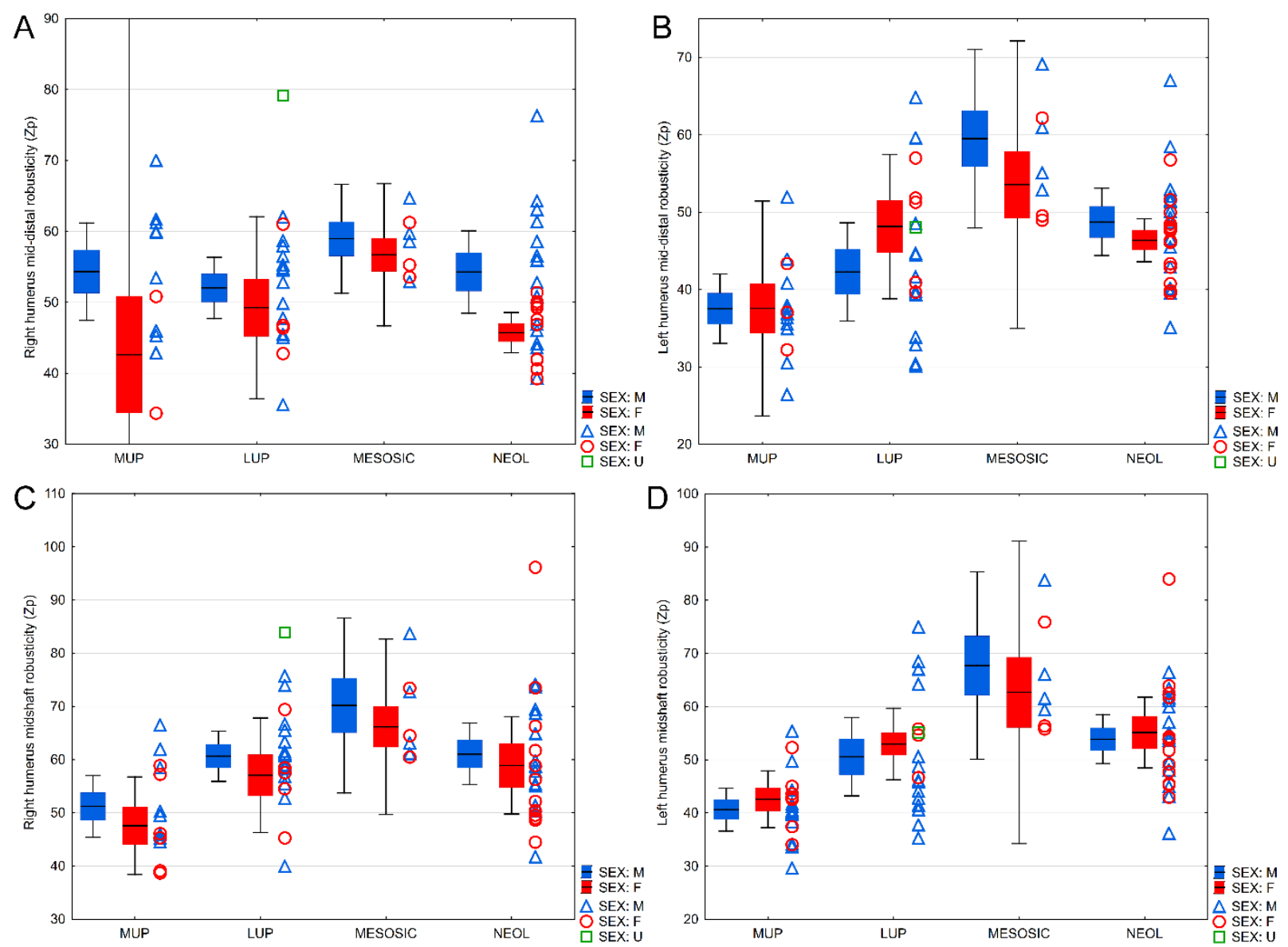

Figure 2 - Robusticity (mechanical rigidity scaled to body size) of the humerus in the Mesolithic Sicilian and comparative samples. Boxplots indicate the mean, the standard error, and 95\% confidence intervals. A) Right mid-distal humerus; B) left mid-distal humerus; C) right midshaft humerus; D) left midshaft humerus. MUP: Mid-Upper Paleolithic; LUP: Late Upper Paleolithic; MESOSIC: Mesolithic Sicilian; NEOL: Ligurian Neolithic. M: males; F: females; U: undetermined sex. 

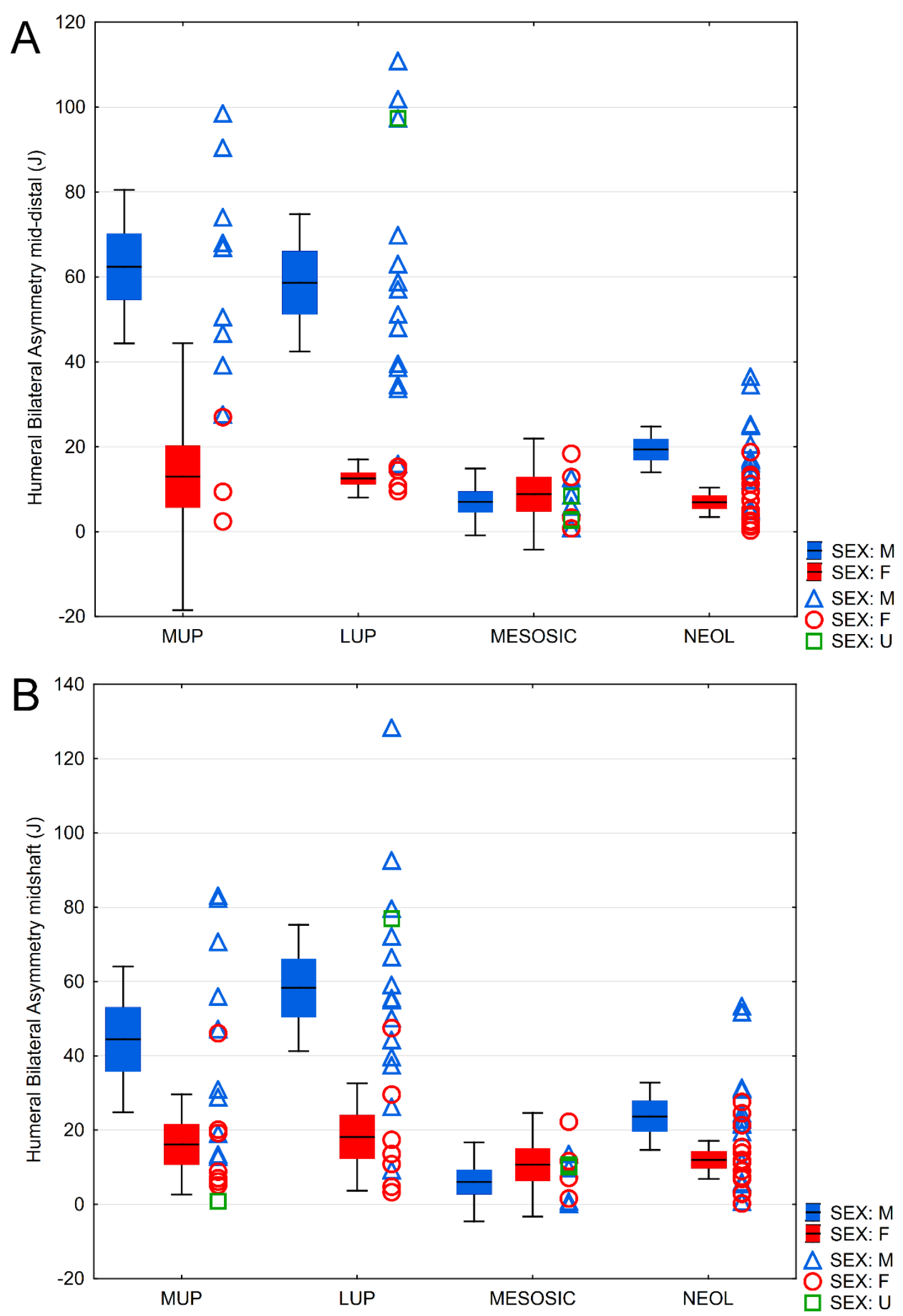

Figure 3 -Humeral bilateral asymmetry in mechanical rigidity, calculated as [(Jmax $\mathrm{Jmin} / \mathrm{Jmin}] \times 100$, in the Mesolithic Sicilian and comparative samples. Boxplots indicate the mean, the standard error, and 95\% confidence intervals. A) mid distal humerus; B) midshaft humerus. MUP: Mid-Upper Paleolithic; LUP: Late Upper Paleolithic; MESOSIC: Mesolithic Sicilian; NEOL: Ligurian Neolithic. M: males; F: females; U: undetermined sex. 

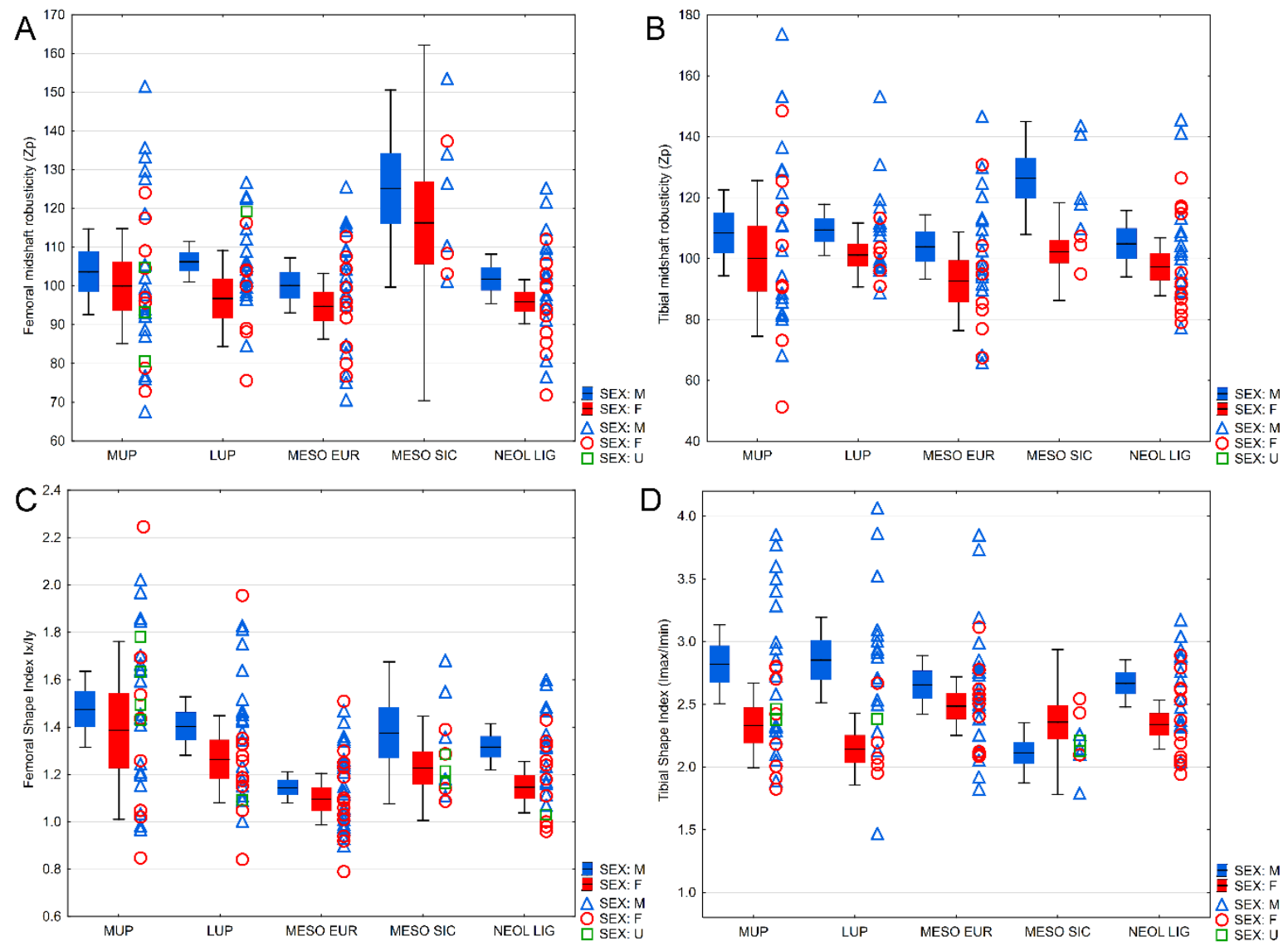

Figure 4 - Robusticity (mechanical rigidity scaled to body size) of the lower limb, and shape indices (Ix/Iy for the femur, Imax/Imin for the tibia) in the Mesolithic Sicilian and comparative samples. Boxplots indicate the mean, the standard error, and 95\% confidence intervals. A) Femoral midshaft robusticity; B) tibial midshaft robusticity; C) femoral shape index Ix/Iy; D) tibial shape index Imax/Imin. MUP: Mid-Upper Paleolithic; LUP: Late Upper Paleolithic; MESOEUR: European Mesolithic; MESOSIC: Mesolithic Sicilian; NEOL: Ligurian Neolithic. M: males; F: females; U: undetermined sex. 